\title{
A circulação da literatura no mundo on-line: os casos de Clarice Lispector e de Caio Fernando Abreu
}

\author{
The circulation of literature in the online world: \\ the cases of Clarice Lispector and Caio Fernando Abreu \\ La circulación de la literatura en el mundo en línea: \\ los casos de Clarice Lispector y Caio Fernando Abreu \\ Manaíra Aires Athayde* \\ Rejane Cristina Rocha*
}

\section{Resumo}

Este artigo procura pensar a circulação da literatura a partir das mais recentes tecnologias de inscrição, apresentando o estudo de caso de dois autores que se tornaram fenômenos de popularidade nas redes sociais. Por um lado, sugerimos que as obras literárias de Clarice Lispector e de Caio Fernando Abreu compartilham uma série de particularidades que tornam os seus textos especialmente atraentes para o universo on-line. Por outro, entendemos que é importante também investigar como o meio digital atua sobre essas obras, que vão sendo editadas, publicadas, reproduzidas, compartilhadas, remixadas, gerenciadas (Manovich, 2011, 2017), de modo a se tornarem um dispositivo de mídia num sistema que sobrevive da convergência dos meios, da construção coletiva e da cultura participativa (Jenkins, 2008).

Palavras-chave: Clarice Lispector, Caio Fernando Abreu, modos de circulação da literatura, mundo digital.

\begin{abstract}
This paper seeks to unpack the circulation that have appeared in the digital age by presenting the case study of two authors that have recently become phenomena of popularity on social media in Brazil. On the one hand, we claim that the literary works by Clarice Lispector and Caio Fernando Abreu share an array of particular features that make these texts especially attractive to the online universe. On the other hand, we suggest that it is equally important to show how the digital medium edits, publishes, reproduces, shares, remixes and manages (Manovich, 2011, 2017) these texts, converting them into a media device integrated into a system that operates through the convergence of media, collective construction, and a participatory culture (Jenkins, 2008).
\end{abstract}

Keywords: Clarice Lispector, Caio Fernando Abreu, forms of literary circulation, digital world.

\begin{abstract}
Resumen
Este artículo busca pensar la circulación de la literatura a partir de las más recientes tecnologías de inscripción, presentando el estudio de caso de dos autores que se convirtieron en fenómenos de popularidad en las redes sociales. Por un lado, sugerimos que las obras literarias de Clarice Lispector y de Caio Fernando Abreu comparten una serie de particularidades que hacen sus textos especialmente atractivos para el universo virtual. Por el otro, hay que comprender también cómo el medio digital actúa sobre esas obras, que van siendo editadas, publicadas, reproducidas, compartidas, remezcladas, gestionadas (Manovich, 2011, 2017), para convertirse en un dispositivo de media en un sistema que sobrevive de la convergencia de los medios, de la construcción colectiva y de la cultura participativa (Jenkins, 2008).
\end{abstract}

Palabras-clave: Clarice Lispector, Caio Fernando Abreu, modos de circulación de la literatura, mundo digital.

\footnotetext{
* Stanford University, Stanford, CA, Estados Unidos. Dorcid.org/0000-0001-8358-6104. E-mail: mana_aires@hotmail.com

${ }^{* *}$ Universidade Federal de São Carlos (UFSCar), São Carlos, SP, Brasil. (Dorcid.org/0000-0002-5944-6846. E-mail: rjncris@ gmail.com
} 
No início de 2019, um jornal português noticiou o "apelo desesperado" em torno de um poema de ampla repercussão na internet (Queirós, 2019). São centenas e centenas de referências a "O mar dos meus olhos", atribuído equivocadamente à escritora Sophia de Mello Breyner Andresen, um dos mais reconhecidos nomes da poesia portuguesa do século XX. Ao mesmo tempo que a notícia "Um falso poema de Sophia que se tornou viral" evidencia os esforços da família da escritora para "desfazer o equívoco", mostra como aqueles versos ganharam uma curiosa adesão de variados públicos leitores, sendo transcritos recorrentemente em diversos meios, desde blogues e redes sociais a artigos acadêmicos, além de já terem sido traduzidos para o alemão e o holandês. A notícia mostra ainda como muitas transcrições chegam mesmo a vir acompanhadas de uma referência bibliográfica, indicando o livro do qual supostamente o poema faz parte e institucionalizando equivocadamente sua autoria. $\mathrm{O}$ intuito da peça jornalística, como é de se esperar, é alertar os leitores para o "ledo engano" à medida que o trata como um dantesco absurdo viabilizado pela web, ajuizando sobre a incapacidade de leitura daqueles que confundem uns "versinhos fraquinhos", de "qualidade mais do que duvidosa", com os versos de "poemas de autoria mais canônica", como seria o caso desta autora, capaz de escrever "um poema maior da lírica portuguesa de todos os tempos", conforme afirma Luís Miguel Queirós (2019).

Mas se esta história nos leva, por um lado, ao teor dramático da "batalha para desassociar a autora de um poema", como aponta um dos comentários na plataforma digital que abriga a notícia, num universo caracterizado por comentários que são quase tão apócrifos quanto muitos dos textos que circulam em rede, por outro, é um daqueles casos que nos ajuda a pensar sobre as novas formas de circulação do literário a partir das mais recentes tecnologias de inscrição. Diante de um contexto anunciado por "batalhas" como esta - a priori pouco eficazes no desterritorializado reino da internet -, a nossa curiosidade está em tentar compreender melhor as relações da literatura com a ecologia de um mundo digital que se vê diante dos crescentes desafios de produzir, gerir, armazenar e fazer circular uma quantidade gigantesca de dados, de maneira que as recentes estratégias de comunicação, implicando transformações substanciais nos códigos de leitura e de escrita, proporcionam o surgimento de novas sensibilidades estéticas. A cultura da estética da informação concebe linguagens cada vez mais dependentes da materialidade digital, diante da qual questionamos: de que forma as mediações tecnológicas permitem a criação de espaços performativos e modos de presença que alteram o sistema de produção de sentido em nossa sociedade? (Portela, 2012).

Pensando na reconfiguração das relações autor-texto-leitor, um desses espaços performativos que nos permite explorar a presença do literário nas novas mídias é o meme - e, mais especificamente, o que vamos chamar de meme literário. No ambiente virtual, fundamentalmente baseado na comunicação escrita e propício ao surgimento de elementos criativos que conjugam as mais diversas formas de texto, o meme aparece como uma unidade espacial, fundada na imitação, que resulta essencialmente na representação visual de um conjunto de informações conjugadas, transmitindo aspectos socioculturais, difundindo juízos de valor e perpetuando padrões de comportamento. É uma de suas características vitais a sua replicação de forma viral, facilitada pelos mecanismos de compartilhamento que grande parte das plataformas digitais disponibilizam, em tempos de experiências compartilhadas. Tanto é que, para Richard Dawkins (1976), responsável por cunhar o termo meme com as bases conceituais que utilizamos hoje, é possível entender tal unidade autônoma de difusão da informação como um "gene de cultura", que se perpetua em condições análogas ao que acontece na evolução genética, com as suas variações, processos seletivos, interrupções ou continuidades, fazendo com que se diversifique ao longo do tempo.

Nesse contexto, quando chamamos à discussão a variante literária, passamos a questionar por que, em ambiente digital, os "genes de cultura" associados a determinados escritores sobrevivem de forma bastante adaptada, replicando-se rapidamente, enquanto outros caem no ostracismo. Nesse mundo de seguidores, likes e compartilhamentos, perscrutamos se seria possível apontar os motivos que levam a que, em redes sociais como o Facebook e o Instagram, certos perfis associados a escritores prosperem mais que outros. Por exemplo, se atendermos a perfis no Facebook de escritores já falecidos (e, portanto, que não podem gerir a própria conta ou consentir que outros o façam), observamos que enquanto Carlos Drummond de Andrade tem 240 mil seguidores e 
Vinicius de Moraes alcança os 154 mil, Manuel Bandeira tem apenas 1,2 mil. Cora Coralina chega aos 276 mil e Cecilia Meireles não ultrapassa os 25 mil. Paulo Leminski tem quase 80 mil seguidores, e as recentes homenageadas da FLIP, principal festival literário do país, Hilda Hilst e Ana Cristina Cesar apresentam 62 mil e 4,5 mil seguidores, respectivamente. Ao passo que os perfis de poetas parecem ser mais propensos a ganhar projeção, os de romancistas revelam, em geral, números mais modestos, com um Guimarães Rosa a contar com 14 mil e um Jorge Amado com quase 25 mil seguidores, enquanto Ariano Suassuna chega aos 45 mil e Raquel de Queiroz não passa dos 2,5 mil. O que se nota é que os números são incongruentes com as representatividades canônicas dos autores, quando pensamos no cenário acadêmico e na fortuna crítica de uma obra, e muitas vezes não condizem nem com as próprias "redescobertas" recentes de nomes promovidos, por exemplo, em festivais e feiras literárias.

Como se pode imaginar, estamos falando de perfis que são geridos de distintas formas, produzindo e divulgando conteúdos diversos, e que não foram necessariamente criados na mesma altura, pelo que é justamente essa não linearidade cronológica do crescimento ou não de uma rede a partir da conjugação de uma série de atores-chaves que se torna um dos pontos importantes da nossa pesquisa. Se, por um lado, sabemos que o modelo evolutivo de transferência da informação pode alterar a recepção de um autor em ambiente virtual, criando caminhos que divergem da evolução do cânone literário, além de proporcionar novas configurações para o exercício editorial, prescindindo de certos princípios e padrões institucionalizados, por outro, é possível afirmar que os memes literários - ou, de maneira mais ampla, as páginas dedicadas aos autores nas redes sociais não apenas transmitem como também (re)configuram, na sua formalização material, a obra, o estilo de um determinado autor, fazendo-os circular por espaços sociais específicos e entre públicos diversos, que recebem, apreendem e ressignificam de maneiras variadas esse conteúdo literário simbólico. Assim é que se pode, a partir de uma mirada que se lance ao conteúdo literário que circula nessas páginas, perceber que o meme é: i) atomizado, uma vez que faz circular uma versão recortada e descontextualizada da obra desses autores, uma versão constituída de frases e pequenos trechos selecionados a partir do gosto pessoal dos administradores das páginas ou em atenção a alguma efeméride; ${ }^{1}$ ii) multimodal, sendo construído pela justaposição ou, pelo menos, pela convivência, na mesma postagem, de matéria verbal e de imagens estáticas (ilustrações e fotografias) ou em movimento (gifs e clipes), com ou sem material sonoro (vocalização de trechos da obra ou temas musicais); iii) customizado, já que um mesmo trecho, de uma mesma obra, pode ser formalizado de maneiras distintas e, então, assumir significados diferentes.

Essas características podem ser delineadas a partir das propriedades que definem fundamentalmente as mediações tecnológicas digitais, ou os "novos meios" (new media), como prefere Lev Manovich (2005), aqueles que são traduzidos em dados numéricos no computador. Qualquer objeto dos novos meios - quer seja um texto, uma imagem, um som - ou é criado como um produto do ambiente digital, ou é convertido para ele a partir de fontes analógicas, em um processo de codificação em linguagem digital. É essa representação numérica que permite que os objetos sejam descritos em termos matemáticos e submetidos à manipulação algorítmica, o que torna possível a modularidade: um texto, um som, uma imagem, quando codificados digitalmente, convertem-se em unidades menores, em elementos discretos que possibilitam a sua manipulação, reconfiguração, combinação... De modo que a facilidade com que materiais pré-existentes podem ser acessados e manipulados, graças a muitas ferramentas de automatização (processadores de texto, de imagem, de som), estimula a lógica da personalização e da variabilidade. Quer dizer, um objeto dos novos meios pode existir em diversas versões, formatos, e ser acessado e compartilhado a partir da demanda do usuário. Quem está lendo este texto pode tê-lo acessado na página html da revista e, assim, está diante da sua versão on-line; pode tê-lo baixado em arquivo PDF e está lendo agora na tela do computador, do tablet ou do celular; pode, ainda, ter impresso todo o texto ou apenas a parte que lhe interessa. Além disso, é

\footnotetext{
${ }^{1}$ É interessante observar como esse movimento também chegou ao livro impresso. Em 2013, a editora Rocco lançou o livro As palavras de Clarice Lispector, uma seleção de trechos e frases organizada tematicamente por um curador. Em 2014, um segundo volume foi lançado, com o título $O$ tempo de Clarice Lispector.
} 
possível também compartilhá-lo, na sua totalidade ou em fragmentos, com outros leitores, que terão as mesmas múltiplas possibilidades de leitura e de compartilhamento.

A característica mais importante dos novos meios, apontada por Manovich (2005), no entanto, é o processo de transcodificação. Para entender sua importância, é necessário antes mesmo compreender que, se os meios técnicos são "o substrato material das formas simbólicas" ou, melhor dizendo, "o elemento material com que ou por meio do qual a informação ou o conteúdo simbólico é fixado e transmitido do produtor para o receptor" (Thompson, 2012, p. 44), eles são também inextricavelmente ligados aos objetos e formas culturais de seu tempo. O que significa dizer que não se constituem nem como superfícies neutras de inscrição, nem como canais neutros de transmissão, interferindo nos objetos e formas culturais que fixam e transmitem, ao mesmo tempo que são por eles modificados. Portanto, se os novos meios possuem duas camadas - uma cultural, outra composta pelos códigos informáticos -, é possível prever que ambas se influenciem mutuamente. E é neste ponto, precisamente, que se situa o nosso mote de investigação, que tem como objetivo analisar como várias versões de um autor emergem na superfície do digital, à medida que nos levam a pensar de que modo as convenções das interfaces do computador, com os seus softwares e hardwares em contínua renovação, interferem na camada cultural dos novos meios, com os seus conteúdos e gêneros emergentes. $\mathrm{O}$ que se viabiliza aqui é uma - julgamos - cada vez mais necessária abordagem interdisciplinar, em que questões sobre as novas mídias são compreendidas como realidades técnicas e, também, socioculturais. Tal abordagem nos permite propor uma análise em que a visada crítica sobre os fenômenos literários no ambiente das mídias digitais ocorre a partir de uma descrição desses fenômenos, que são literários, mas são, também, técnico-midiáticos.

Para tanto, trataremos de dois casos proeminentes de escritores brasileiros nas redes sociais: Clarice Lispector (1920-1977) e Caio Fernando Abreu (1948-1996). Acontece que, se agora, em meados de 2019, ambos são de longe os autores emulados (cuja construção é fictícia, tornando-os um revival literário popularizado nas redes) que possuem maiores projeções on-line no Brasil, é preciso que se diga que tal cenário já despontava em meados de 2013, como mostra o estudo pioneiro "Literatura, Twitter e Facebook: A economia dos likes e do RTS dos usuários fãs de literatura brasileira nas redes sociais", de Fabio Malini, baseado em técnicas da data science para apresentar gráficos que comparam as estratégias de difusão de escritores na rede. Na altura, as páginas de Clarice e de Caio (que cooptavam o maior número de seguidores no Facebook: 743 mil e 373 mil, respectivamente) eram as que "apresentavam maior inter-relação. Logo, mais afinidade de gosto entre seus usuários" (Malini, 2014, p. 209), como assinala o artigo. O que quer dizer que já havia um grande diálogo entre os fãs das páginas dos dois escritores - "quem curte Clarice, curte Caio" (Malini, 2014, p. 207) -, o que leva a um notável crescimento na valorização de determinados conteúdos em detrimento de outros, reiterando as bolhas de conteúdo. O artigo revela ainda que "há certa proximidade nas estratégias dessas páginas em construir a relação entre os seus públicos" (Malini, 2014, p. 210), caracterizados como heterogêneos, com uma interação feita por um grande número de usuários curtindo os mesmos conteúdos e, ao mesmo tempo, menos especializados em literatura e com um perfil menos propício ao de mediador cultural.

Assim, motivada pelos desdobramentos desse contexto, surge a proposta deste trabalho. O nosso intuito é analisar o desenvolvimento das páginas mais populares de Clarice Lispector e de Caio Fernando Abreu no Facebook e no Instagram, acompanhando todas as suas diferentes fases, desde quando foram criadas aos dias que correm, procurando observar os tipos de conteúdo que são mais trabalhados e as formas de edição que são adotadas ao longo do tempo. O que se busca é observar o modo como esses perfis emulados lidam com características temáticas e de estilo dos autores que representam, criando-lhes novas imagens e reiterando outras concebidas pela crítica especializada. Importa aqui pensar a forma como essas fanpages mobilizam diferentes estratégias de apropriação da imagem de um autor e de suas obras literárias, e por isso o que se fará é associar perspectivas críticas literárias sobre as obras de Clarice Lispector e de Caio Fernando Abreu à análise de informações extraídas e aspectos observados naquelas páginas, traçando um caminho que compactua o teor especulativo da crítica literária às possibilidades exploratórias da observação empírica motivada pelo universo digital. Dessa maneira, o que nos motiva, diante das limitações de extensão deste 
trabalho, é analisar os múltiplos movimentos do texto literário nas redes sociais e como essa dinâmica coaduna com aspectos relevantes das obras dos autores reproduzidos, editados, compartilhados, remixados. O que procuraremos explorar nas próximas páginas são as faces sem rosto recriadas a partir da camada informática, que vão dando novos significados culturais às imagens de Clarice Lispector e de Caio Fernando Abreu ao torná-los estranhamente familiares a diversos públicos destes tempos high tech.

\section{Caio Fernando Abreu, para além de uma tendência}

No post de um blogue, de 25 de junho de 2011, a professora Ana Gabriela escreve: “Eu gosto de Clarice desde 2002, quando entrei na faculdade e recentemente (coisa de um ano e meio) tenho lido bastante a obra de Caio. Tenho observado que muitas pessoas tem os dois como seus escritores preferidos e acredito que seja porque eles têm diversos pontos em comum e ultimamente viraram 'modinha' graças às redes sociais, né?!" (Vieira, 2011). O texto segue questionando quantas pessoas curtem os dois escritores sem nunca ter realmente lido seus livros. Curiosamente, pouco tempo antes, naquele mesmo ano, é publicada a notícia "Morto há 15 anos, Caio Fernando Abreu está vivo nas redes sociais, é cultuado por jovens e ganha livros, documentário e peça" (Castro, 2011), indicando o fenômeno midiático que ganhava visibilidade naquela altura. No ano seguinte, mais uma matéria anuncia a popularidade do "Autor que renasceu na internet: Caio Fernando Abreu vira ídolo teen 16 anos depois de sua morte", conforme lemos na Época de 30 de março de 2012 (Venticinque e Ayub, 2002). E ainda, mais recentemente, é a vez do El País publicar "Caio Fernando Abreu é jovem como sempre, relevante como nunca" (Avendaño, 2018), no dia em que o escritor faria 70 anos, em 12 de setembro de 2018. Como se pode notar pelos títulos das notícias, bem como pelo trecho do post que reproduzimos, parece impossível falar na redescoberta da obra de Caio Fernando Abreu ao longo desta década sem associá-la à grande repercussão que passou a ter na web.

As três notícias têm em comum o interesse em tentar desvendar características da obra do escritor que tenham contribuído para torná-lo tão popular nas redes sociais, o que acaba dando a entender que a obra por si só já justifica esse êxito. Propomos, no entanto, acrescentar sensivelmente à questão a importância das formalizações materiais dos modos de circulação da literatura no mundo digital, perscrutando como novos mecanismos determinam o modus operandi da nossa "cultura do software" (Manovich, 2011), em que a concepção da realidade é cada vez mais dependente de programas digitais. Em outras palavras, além das particularidades literárias de uma obra que se acomoda ao universo on-line, é preciso compreender também como o meio digital atua sobre essa obra, que vai sendo editada, publicada, reproduzida, compartilhada, remixada, gerenciada, de modo a se tornar um dispositivo de mídia num sistema que sobrevive da convergência dos meios, da construção coletiva e da cultura participativa (Jenkins, 2008). É neste sentido que podemos dizer que Caio Fernando Abreu criou um universo literário que, ao possibilitar que públicos mais jovens se reconhecessem ou se identificassem de alguma maneira, foi sendo transformado numa "mensagem em design poético" (Manovich, 2017, p. 95, tradução nossa) por esses mesmos públicos, caracterizados por gerações cada vez mais hábeis na manipulação de ferramentas digitais:

A sociedade estética é também aquela em que as tribos das mídias urbanas/sociais emergem e se sustentam através de escolhas e experiências estéticas. Nas palavras de Michel Maffesoli, que desenvolveu a análise da "tribo urbana" ainda nos anos 80 , "ela se refere a um certo ambiente, um estado de espírito, e ela pode ser preferencialmente expressada através de estilos de vida que favorecem a aparência e a forma". E ambiente e estado de espírito são exatamente a "mensagem" do Instagramism (Manovich, 2017, p. 118, tradução e grifo nossos).

Nesta sociedade da estética da informação, a noção de lifestyle vai se tornando um valor primordial para os jovens públicos globais que crescem sendo estimulados a produzir vozes visuais tecnologicamente sofisticadas. Ao adquirirem novas funções sociais, as escolhas e experiências estéticas se manifestam, na iconografia digital, através da conjugação de elementos performáticos que, favorecendo a aparência e realçando a forma, geralmente procuram revelar 
um certo ambiente, um certo estado de espírito em imagens que transmitem a sensação de que foi possível captar a atmosfera de um momento único. É assim que, segundo Manovich (2017), surge o Instagramism, entendido como o visualmente poderoso estilo de vida criado por uma sociedade cada vez mais dependente de softwares, e claro está, um dos seus principais aspectos é o enfoque no mood e na atmosfera, e não propriamente na representação, o que parece bastante significativo quando pensamos no caso de um escritor como Caio Fernando Abreu.

Poderíamos dizer que a insistência obsessiva deste autor em descrever seus estados de humor, encenar modos de sentir e partilhar inúmeras experiências (não à toa desenvolve uma notável epistolografia) converte-se, nas redes sociais, em memes literários cuja "mensagem em design poético" compreende aquela exaltação das emoções em torno de um momento vivido, a definição de ânimo que transmite um estado de espírito, a contemplação descritiva das coisas. Se, por um lado, a autoficção - essa insistente performance do $e u$ - recorrente na escrita de Caio Fernando Abreu parece anunciar o espaço narcisístico aprofundado com as narrativas digitais, frutos de uma autoedição contínua que fazemos de nós mesmos, por outro, o interesse em difundir a obra do autor, garantindo a veracidade das citações utilizadas nos memes, não é maior que a sua própria imagem projetada nas redes sociais. Os perfis que recebem o nome do autor, independentemente da fidedignidade das citações utilizadas nos memes, acabam por transformá-lo em uma marca (brand), ${ }^{2}$ que neste caso se beneficia de Caio Fernando Abreu enquanto escritor que conseguiu criar, em textos de evidente intensidade emocional, uma notável atmosfera de intimidade com o leitor.

Tanto é que, se observarmos a página com o nome Caio Fernando Abreu que mais seguidores tem no Facebook (@caiofernandoabreu), reunindo hoje cerca de 712 mil, ${ }^{3}$ o tipo de meme que prevaleceu durante mais tempo desde a criação do perfil, em 12 de julho de 2010, é aquele composto com apenas uma fotografia e, ao lado dela, na caixa de mensagem do post, uma frase ou parágrafo supostamente retirado da obra do autor, sem, no entanto, o nome dele constar na publicação (Figura 1). Estamos falando de memes criados com fotografias que, parecendo ter sido retiradas de bancos de imagens, são geralmente em preto e branco ou modificadas com filtros que reproduzem efeitos vintage, procurando restaurar a convenção visual associada às recordações e a ambientes nostálgicos. O que importa não é criar narrativas que representem ações, mas descrições repletas de sutilezas que revelem, mais do que um modo de ser, aquilo que se está sendo naquele preciso momento, em detrimento do que se está fazendo. Quer dizer, não se pretende trazer à tona histórias nostálgicas a partir das imagens, com as suas respectivas citações, mas fazer com que as escolhas estéticas, tais como a redução da escala de cinzas, o contraste ou a saturação de cores, tornem-se metáforas para os contrastes emocionais, as sensações e os prazeres ocasionais, as intempéries. Por isso, muitas vezes as fotos que compõem esses memes revelam parcialmente ou mesmo não revelam o rosto dos fotografados, optando por silhuetas e sombras, o que amplia consideravelmente o seu poder sugestivo e potencia um efeito ainda maior de reconhecimento do público com aquilo que vê/lê, permitindo o usuário se identificar com aquela imagem que nem rosto tem - ou melhor, que se customiza de usuário para usuário. $\mathrm{O}$ curioso é que foi esse tipo de meme que alavancou aquela página no Facebook e predominou ao longo de 2014 e 2017 (incluindo, portanto, todo o seu auge, entre 2015 e 2016), sendo adotado justamente quando os administradores criaram uma conta no Instagram (\#escritorcfabreu) com o nome do autor, em abril de 2015, cinco anos depois que abriram a conta no Facebook (Figura 2).

\footnotetext{
${ }^{2}$ É interessante notar que a frase "Que seja doce" - repetida várias vezes no final do conto "Os dragões não conhecem o paraíso", que faz parte do livro homônimo, publicado em 1988 - tornou-se uma espécie de slogan associado ao nome de Caio Fernando Abreu, com vários memes a reproduzi-la e com a publicação de fotografias que mostram desde tatuagens a grafites feitos com a frase. Além disso, a página no Facebook @ caiofernandoabreu, ainda numa primeira fase, em 2013, quando não havia regularidade nas suas publicações, nem padronização da concepção dos memes, começou a comercializar objetos com a frase, tais como blusas, toalhas, chaveiros, bottons, revelando o interesse dos administradores do perfil em fazer dele um negócio.

${ }^{3}$ Lembremos que há uma diferença entre a quantidade de pessoas que curte e a quantidade de pessoas que segue uma página. Os usuários que curtem a fanpage estão assumindo que gostam daquela personalidade referenciada no título, mas não necessariamente querem receber o conteúdo da página, tal como o querem os seguidores, que no caso da @ caiofernandoabreu são 710 mil. Além disso, também há os grupos fechados, em que existe um moderador que aceita ou não os pedidos de participação no grupo e também controla o tipo de postagem que os membros fazem na timeline. No caso de Caio Fernando Abreu, há um grupo fechado com mais de 12 mil membros, que foi criado em 11 de junho de 2018.
} 


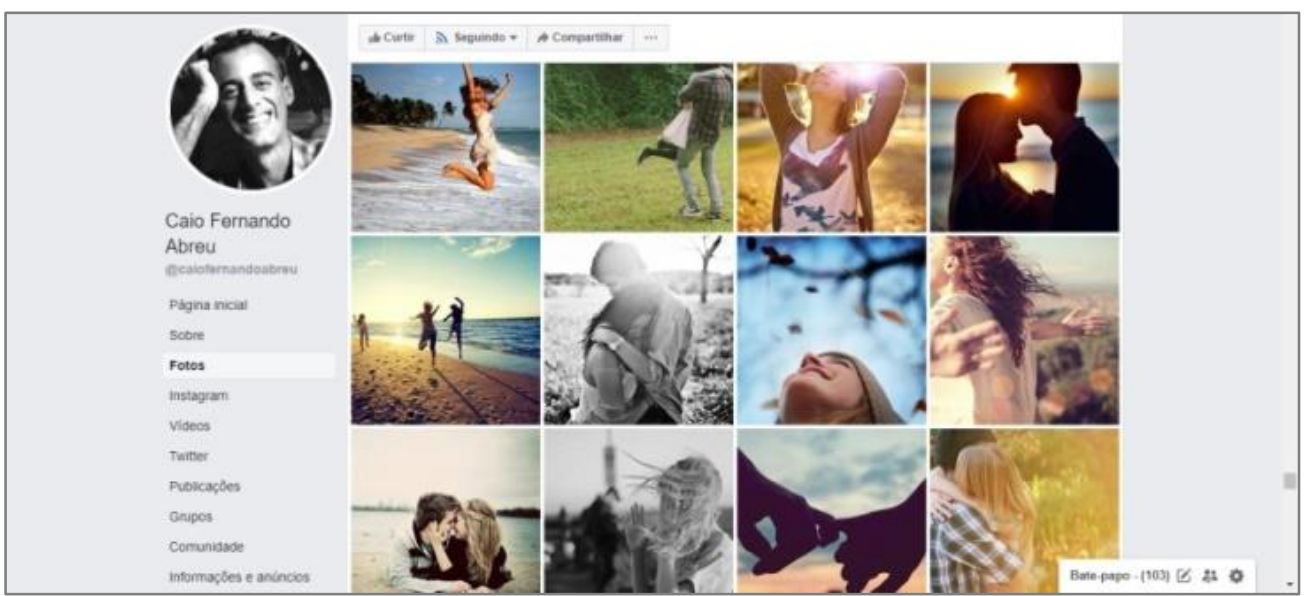

Figura 1 - Reprodução da fanpage @caiofernandoabreu, no Facebook.

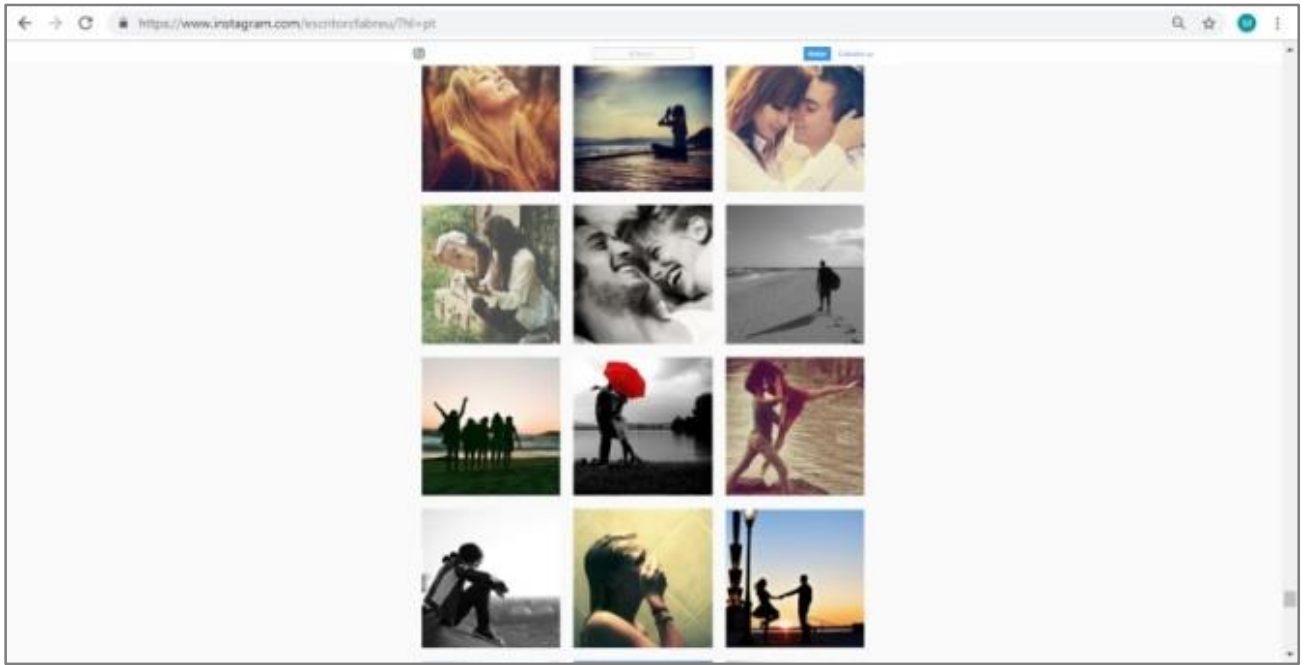

Figura 2 - Reprodução da página \#escritorcfabreu, no Instagram. ${ }^{4}$

Assim, a partir daquela altura, os dois perfis começaram a ser "alimentados" com o mesmo tipo de conteúdo, ${ }^{5}$ o que gerou uma situação ainda mais curiosa: se a página no Facebook prosperou com aquele modelo de meme que foi produzido seguindo a lógica visual que florescia no Instagram, de modo contrário, a página no Instagram não conseguiu ultrapassar até hoje os 14 mil seguidores (ou seja, tem cerca de cinquenta vezes menos adeptos). Enquanto um mesmo meme no Facebook atingia os 6,4 mil likes e 1.332 compartilhamentos, por exemplo, no Instagram não chegava aos 200 likes. A conjectura provável para que tal apelo visual prosperasse no mundo do Facebook é que, naquele momento, além de não haver outro perfil diretamente concorrente na mesma rede social, o tipo de meme que adotaram conseguiu se acomodar à diversidade do público que frequentava a plataforma, ao passo que no Instagram já existiam outros perfis concorrentes que decerto atendiam melhor as exigências de uma audiência mais segmentada, para a qual aquele modelo de meme não era de todo novidade,

\footnotetext{
${ }^{4}$ Os dois frames, nas figuras 1 e 2 , mostram o tipo de meme que prevaleceu ao longo da história das fanpages, criadas pelos mesmos administradores.

${ }^{5}$ É importante sublinhar que, embora o modelo de meme fosse o mesmo, nem sempre os memes se repetiam nas duas páginas e, caso fossem replicados, muitas vezes eram postados em dias diferentes, embora geralmente na mesma época, com apenas alguns dias espaçados.
} 
sendo inclusive uma das tendências (trends) de maior longevidade. É preciso lembrar que as migrações mais substanciais do Facebook (criado em 2004) para o Instagram (que surgiu somente em 2010) começaram a acontecer a partir de 2017,6 de modo que o público das duas redes sociais, nos meados da década, era ainda bastante diferente: o Instagram continuava associado a jovens que já pouco frequentavam o Facebook e também a nichos de artistas, profissionais e entusiastas ligados à imagem e ao design.

Quando surgiu o mencionado perfil \#escritorcfabreu no Instagram, já lá havia o \#caiofernandoabreu, criado a 9 de maio de 2013, portanto, dois anos antes do outro. A página, que aparenta ter um perfil menos comercial que os outros dois casos, embora apresente o maior número de seguidores no Instagram, com atuais 127 mil, é certamente o caso que mais chama a atenção quanto aos modos de circulação do nome e da obra de Caio Fernando Abreu naquelas duas redes sociais. A começar pela importância da mancha gráfica, claramente visível na timeline do perfil, em que logo se nota que a maior parte dos memes não possui aquele modelo que assinalamos anteriormente - o grande destaque é dado ao texto. Na maioria das vezes não há fotografias, mas apenas um plano de fundo preenchido com uma cor e a citação ocupando quase todo o espaço, geralmente com letras grandes e fontes variáveis, que vão das tipografias mais comuns às caligráficas. Além disso, outro elemento que se sobressai é a inscrição do nome do autor no final de cada excerto, que pode ser "Caio Fernando Abreu", "Caio F. Abreu" ou a sigla "CFA". Desde o início de \#caiofernandoabreu, observamos que inscrever a citação dentro do espaço gráfico do meme e assinalar o nome do autor como uma brand foram preocupações que não vimos nas outras duas páginas, embora os seus memes já revelassem a importância da citação independentemente da imagem (muitas vezes repetiam a fotografia, mas com citações diferentes, gerando quantidade de likes bastante díspares). É certo que a inserção da referência de cada citação nos memes é baixíssima nos três perfis, mas enquanto em \#caiofernandoabreu podemos assinalar que $2 \%$ dos memes fazem menção à fonte de onde aquele excerto foi retirado, nos perfis @caiofernandoabreu e \#escritorcfabreu não encontramos absolutamente nenhum meme que contenha referência bibliográfica. Além disso, ao procurarmos localizar na obra do escritor as citações dos quinze memes com maior popularidade anual desde que surgiu \#caiofernandoabreu, conseguimos encontrar cerca de $33 \%$ do conteúdo, dos quais $56 \%$ são trechos retirados de cartas, $24 \%$ são trechos retirados de contos ou romances e $20 \%$ são retirados de crônicas.

Para já, tais números nos levam a perceber dois pontos importantes quanto à divulgação desta obra literária nas redes sociais. Primeiro, o perfil que parece se consolidar com o tempo, apresentando uma linha ascendente até agora, é aquele que deu ênfase ao texto literário e à associação do trecho destacado ao nome do autor. Ainda que o pacto de confiabilidade na origem das citações seja bastante frágil no mundo on-line - lembremos que mesmo num perfil como o \#caiofernandoabreu quase $25 \%$ das citações aparecem sem a indicação da autoria ${ }^{7}$ e muitas delas fazem parte dos memes mais curtidos -, a verdade é que a atribuição da autoria às citações e a inserção delas na composição imagética do meme contribuíram para que houvesse progressivamente o aumento da interatividade na página, ampliando a participação colaborativa da comunidade e, mais recentemente, proporcionando transformações em direção ao que Henry Jenkins (2008, p. 7-8) chama de "convergência", a partir da produção midiática cooperativa e da reapropriação de conteúdos, acelerando comportamentos migratórios dos públicos dos meios de comunicação e incentivando-os a fazer conexões em meio a conteúdos midiáticos dispersos.

É justamente o que acontece quando nos deparamos, na linha cronológica recente, com o que podemos chamar de terceira fase dos perfis@caiofernandoabreu e \#escritorcfabreu. Se

\footnotetext{
${ }^{6}$ É interessante observar que a queda na quantidade de compartilhamentos de memes no Facebook parece ser um dos indícios desse movimento migratório. Se entre 2010 e 2014 era notadamente mais fácil atingir milhares de compartilhamentos (mais de mil por meme), a partir de 2015 (quando públicos mais jovens começaram a estar mais ou somente no Instagram), observa-se uma diminuição substancial, atingindo apenas algumas poucas centenas. De 2017 para cá (com uma migração massiva de outros tipos de públicos), o mais comum é vermos apenas algumas dezenas de compartilhamentos a cada meme, alterando visivelmente a reprodução e a circulação de conteúdo, de modo que talvez tenha sido também por isso que surgiu a motivação para (re)produzir um novo tipo de meme.

${ }^{7}$ Ainda que na web circulem PDFs (versões digitais disponibilizadas pela equipe Digital Source, do Google Groups, num projeto intitulado "Coleção Caio 3D") da obra completa de Caio Fernando Abreu e do volume de cartas editado por Italo Moriconi. Alguns dos perfis, inclusive, disponibilizam tais PDFs.
} 
antes era possível afirmar que parte esmagadora de suas postagens nem sequer parecia corresponder ao estilo textual do autor, acontece que, a partir de meados de 2018 (altura em que se intensificaram os debates sobre fake news e o cuidado com a origem das fontes na internet), as páginas abandonaram aquele modelo de meme descrito (Figura 3), passando a publicar memes que, embora continuem a ter como base a fotografia, agora concedem grande destaque ao texto (Figura 4). O que houve foi uma padronização do design do produto publicado: no primeiro momento, de junho a agosto de 2018, os memes são criados com a citação em caixa alta e o nome do autor em letra cursiva, aludindo a uma espécie de assinatura. Depois, há um longo hiato sem postagem alguma (o que pode indicar uma mudança de gestores) e a página retoma as publicações em janeiro de 2019, ainda a contar com o recurso da fotografia, mas a conferir grande realce à citação, que aparece sempre com a mesma fonte typewriter, a partir de um marca-texto branco utilizado para criar contornos (Figuras 5 e 6). Se pensarmos, então, nos conteúdos convergentes de @caiofernandoabreu e \#escritorcfabreu, na fase mais recente, mesmo que só tenhamos conseguido identificar $25 \%$ das citações, $61,5 \%$ delas são trechos extraídos de cartas, $23,1 \%$ são trechos de contos de diferentes livros, e 15,4\% são trechos de crônicas.

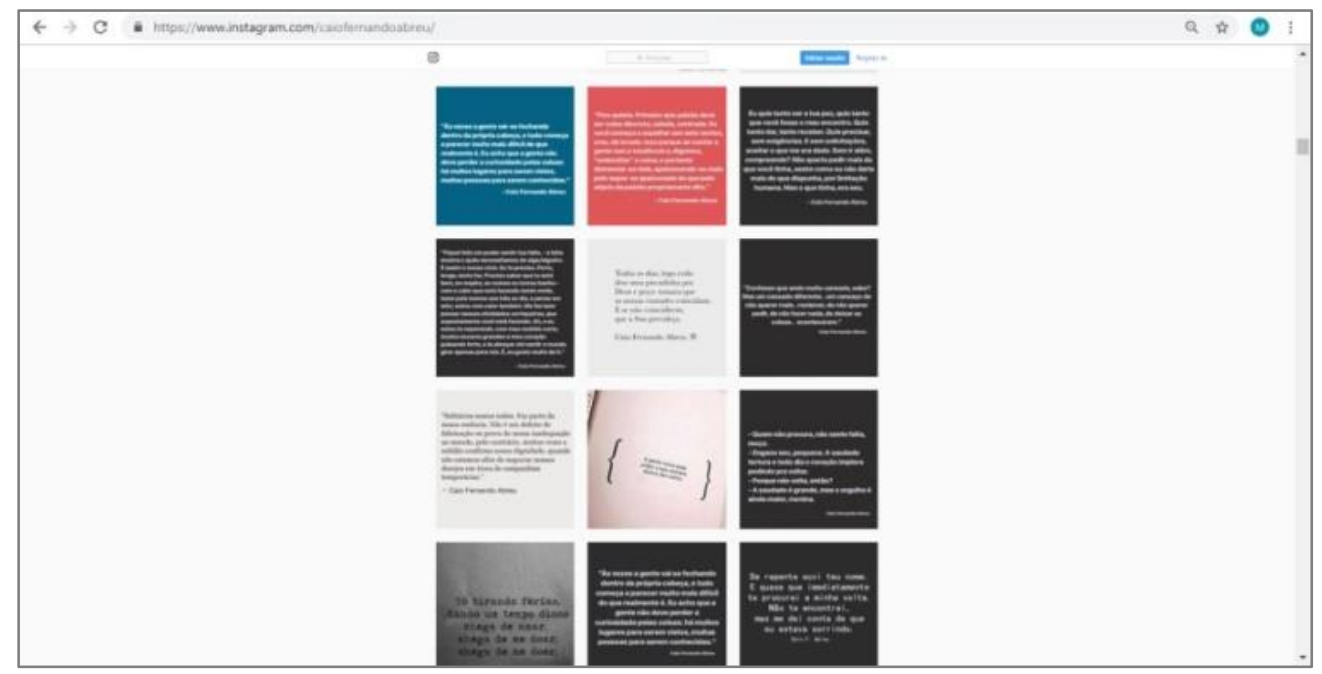

Figura 3 - Reprodução da timeline da página \#caiofernandoabreu, no Instagram, em 2018.

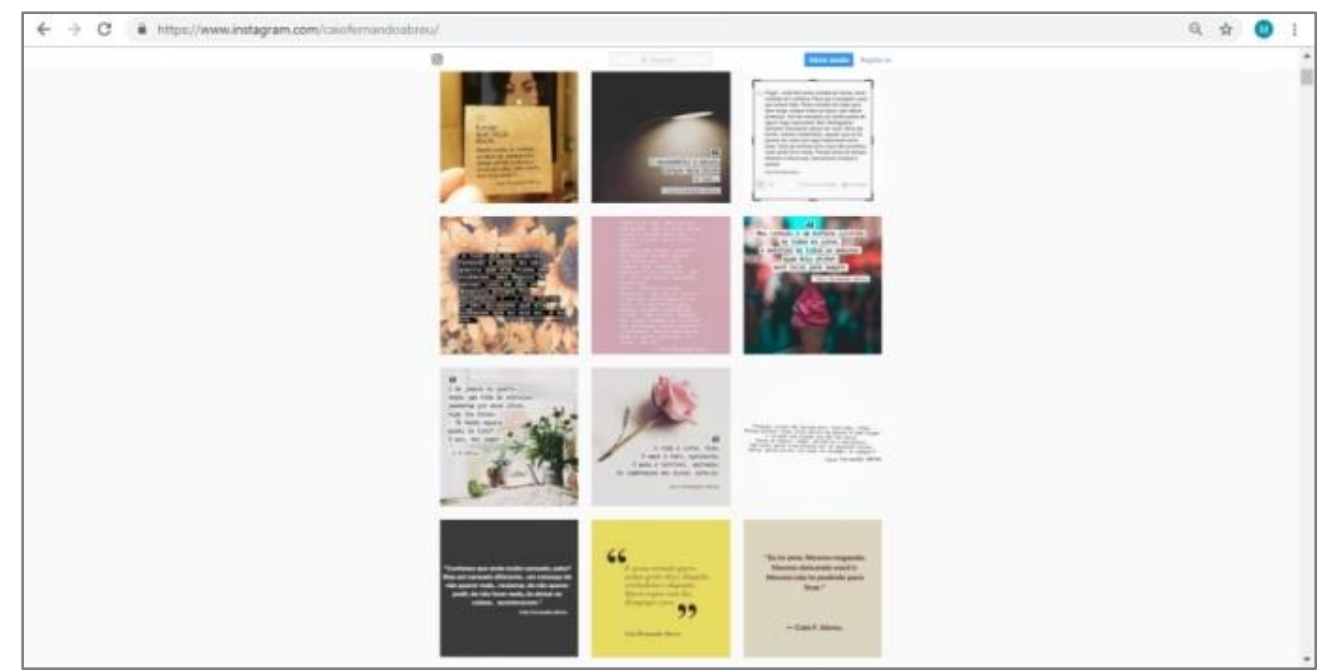

Figura 4 - Reprodução da página em 2019, com a publicação de memes padronizados também encontrados em outros perfis. 

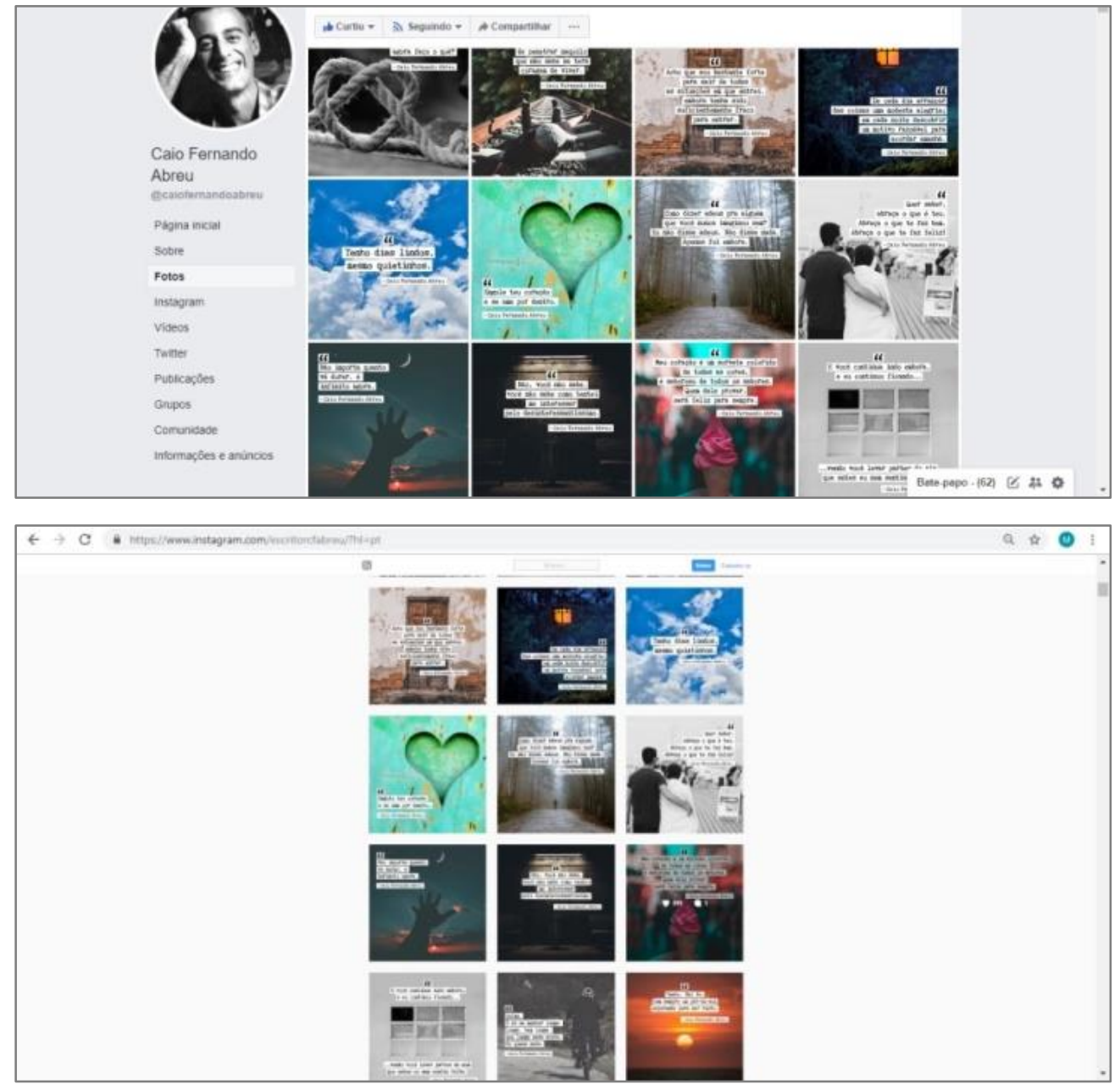

Figuras 5 e 6 - Terceira fase dos perfis @caiofernandoabreu e \#escritorcfabreu, com a padronização do design e a inscrição destacada da citação e do nome do autor no espaço gráfico do meme. ${ }^{8}$

Assim, pressupomos que, de alguma forma, as esferas de publicação do perfil \#caiofernandoabreu influenciaram alterações na forma de gestão dos perfis @ caiofernandoabreu e \#escritorcfabreu, de modo que hoje os três passaram a compartilhar memes com concepções mais próximas, se não, em alguns casos, o mesmo. É o que acontece com o meme feito a partir da citação "Meu coração é um sorvete colorido de todas as cores, é saboroso de todos os sabores. Quem dele provar será feliz para sempre", que se encontra numa crônica de Pequenas epifanias - curioso é observar que tal meme, publicado em fevereiro deste ano, apresenta 3240 likes, 389 likes e 196 likes nos respectivos perfis \#caiofernandoabreu, \#escritorcfabreu e @caiofernandoabreu. O que, aliás, nos leva ainda a outra observação sobre a difusão do literário no mundo das redes sociais, que tem a ver com os livros mais evocados e o padrão adotado no conteúdo das publicações. Neste sentido, parece bastante sugestivo que a obra mais citada, claro está, seja Pequenas epifanias ${ }^{9}$, que reúne postumamente o trabalho cronístico do autor, publicado desde meados de 1980 até pouco antes de sua morte, em 1996, por complicações trazidas pelo HIV. Como lembra Antonio Gonçalves Filho (2014, p. 7) na apresentação daquele livro, Caio Fernando Abreu está "disposto a fazer da crônica uma narrativa explicitamente autobiográfica e escandalosamente literária", o que aponta para

\footnotetext{
${ }^{8}$ Observamos aqui o movimento de convergência de conteúdos que acontece nas redes sociais.

${ }^{9}$ Recordemos que Pequenas epifanias, organizado por Gil França Veloso, foi publicado pela primeira vez em maio de 1996, três meses depois da morte de Caio Fernando Abreu, pela Editora Sulina.
} 
aquela atmosfera do self de que falávamos anteriormente. Mas quer nos parecer ainda mais significativo que não tenhamos encontrado memes com citações de cunho político ou social, em se tratando de um escritor que tanto se dedicou a temas que foram retomados com grande visibilidade em nossos dias, a saber, por exemplo, reflexões sobre a ditadura militar, abertura para falar sobre a homossexualidade, exposição pública de questões relacionadas à Aids. Os conteúdos que circulam nas redes sociais convergem quanto ao recorte que dão à obra, em que o grande interesse está nas "pequenas epifanias" do cotidiano - o mood, as encenações do $e u$ - reveladas por este "fotógrafo da fragmentação contemporânea", como o perfil no Facebook sintomaticamente apresenta o escritor (tal como consta também na Wikipédia), realçando basicamente o seu "estilo econômico e bem pessoal".

$7 \mathrm{~A}$

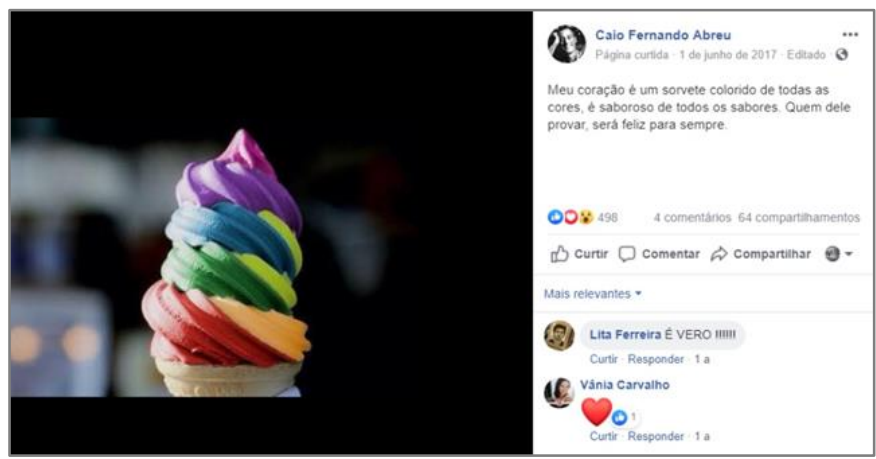

$7 \mathrm{~B}$

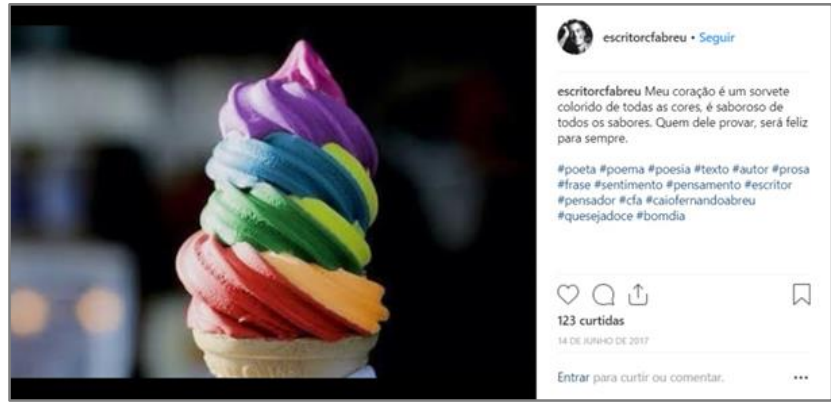

7C

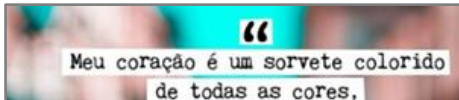

Meu coraçáo é um sorvete colorido
de todas as cores,

é saboroso de todos os sabores.

Quem dele provar,

será feliz para sempre.

-Caio Pernando Abreu
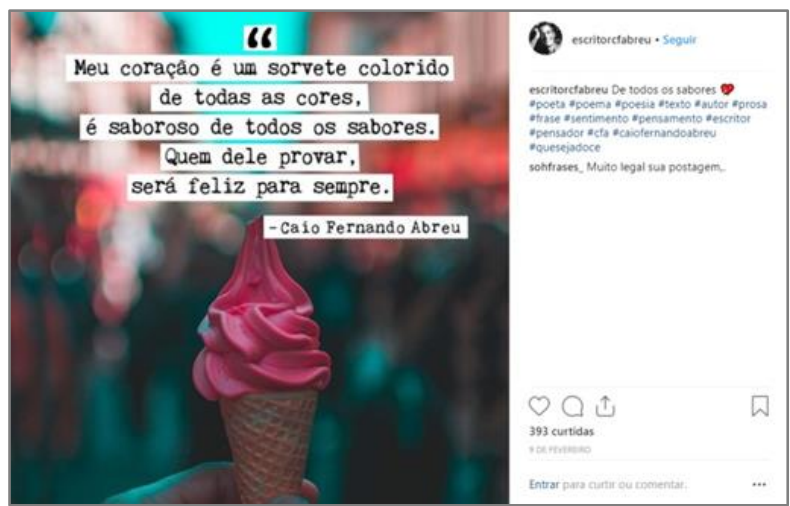
$7 \mathrm{D}$

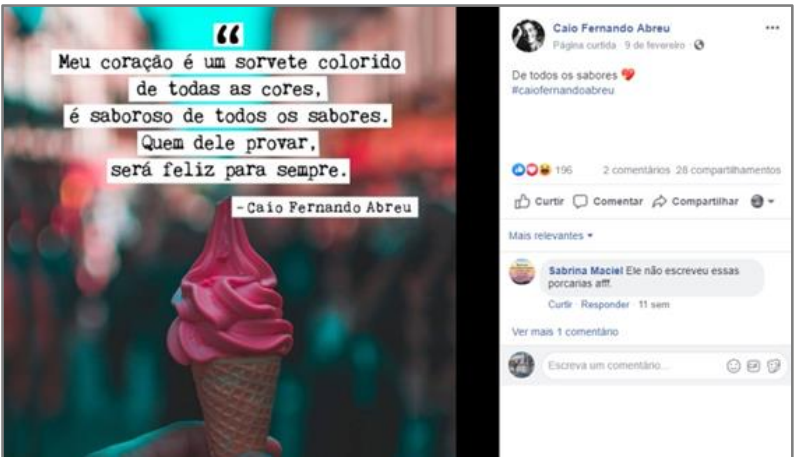

$7 \mathrm{E}$
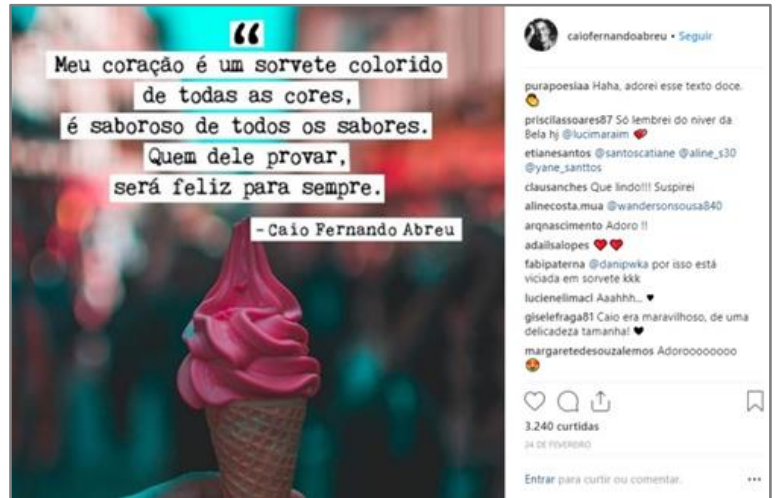

Figuras 7A, 7B, 7C, 7D e 7E - A mesma citação, retirada do livro de crônicas Pequenas epifanias, é reciclada várias vezes pelos três perfis, com os dois modelos de memes adotados em diferentes fases. ${ }^{10}$

Começando a escrever nos anos 1960, ainda muito jovem, e sendo reconhecido pelas nuances pop-contraculturais e marginais das duas décadas seguintes, "o flerte com a linguagem juvenil" e "o mergulho no consolo místico (ou cósmico)" (Moriconi, 2002, p. 6) ficam também bastante evidentes na volumosa correspondência de Caio Fernando Abreu. Por isso, é ainda mais substancial observar que, nos três perfis, as suas cartas são citadas mais que qualquer outra obra, tendo se tornado uma fonte poderosa a publicação do livro Cartas, organizado por Italo Moriconi, em 2002 (e reeditado em 2006):

$\mathrm{Na}$ medida em que o trabalho de Caio era escrever, as cartas fazem parte do mesmo movimento produtivo de que brotam suas crônicas, suas ficções, suas peças teatrais, suas resenhas e matérias jornalísticas, assim como presumivelmente seu diário, ainda não revelado ao público. Tudo produto de um mesmo processo de vida se fazendo na escrita, enunciação e enunciado condicionando-se mutuamente, escrita alimentando-se de vida, vida transcendida pelo simbólico, metáfora que universaliza (Moriconi, 2002, p. 10).

Como se pode ver, a origem dos trechos recorrentes está em textos que, diluindo fronteiras entre gêneros discursivos, utilizam artifícios ficcionais para criar registros confessionais e enfatizar tons de testemunhos arraigados em experiências vividas - e "experiência" é um conceito-chave da atmosfera do self promovida por um mundo cada vez mais on-line. Essa utilização recursiva de crônicas e de cartas, territórios férteis para a invenção do $e u$, evidencia, portanto, que a edição da obra de Caio Fernando Abreu nas redes sociais explora exaustivamente a parte de sua escrita marcada por acentuadas

\footnotetext{
${ }^{10}$ Em $1^{\circ}$ de junho de 2017, a citação que se repete nos memes selecionados acima aparece no @ caiofernandoabreu (7A) com quase 500 likes, e a 14 de junho do mesmo ano é publicada no Instagram \#escritorcfabreu (7B), recebendo 123 curtidas. Depois, já com a alteração do tipo de meme adotado, as duas redes publicam a citação em 9 de fevereiro de 2019, obtendo 393 curtidas no Instagram (7C) e 196 likes no Facebook (7D). Já o perfil no Instagram \#caiofernandoabreu publica o mesmo meme (7E) a 24 de fevereiro, recebendo 3.240 likes. Tais dados nos levam a pensar nos processos que correm nesta nossa atual "cultura da convergência", a partir da reapropriação de conteúdos, da produção midiática cooperativa e da cultura participativa. Prints realizados em 29 abr. 2019.
} 
oscilações, indo da euforia à depressão, de paixões efusivas à agonia pessimista, da exaltação da liberdade ao sofrimento de uma vida emocional e profissionalmente instável, beirando sempre os extremos do entusiasmo e da angústia. Em tempos obcecados por questões de identidade, quiçá a identificação de sua imagem com a "coragem de ser" tenha impulsionado o aparecimento de perfis que se acomodam confortavelmente às peculiaridades dos públicos nesta era digital.

Poderíamos mesmo dizer que a imagem projetada de Caio Fernando Abreu que brota nas redes sociais personifica o teor dramático de um mundo no qual a crescente possibilidade de escolhas vem acompanhada da franca perda de estabilidade, representando os ímpetos das atuais gerações frustradas que nasceram em tempos de redemocratização pouco a pouco empalidecidos com o quase sem-lugar das prospecções utópicas. Quer dizer, se aquele prometido mundo melhor não veio, apesar de toda a revolução tecnológica, o que essas novas gerações passaram a criar, a partir dessa revolução, é uma imagem idealista, quase utópica, do "lifestyle perfeito", nesta sociedade que produz cada vez mais uma imagem photoshopada de si mesma, admitindo que a distância entre a realidade on e a realidade off-line diminua substancialmente. Para essas novas gerações hipermidiatizadas, o fato de se copiar estilos, estratégias e sensibilidades não as torna menos autênticas ou menos reais, "pois o que é real, para elas, é o que sentem, suas emoções e suas preferências estéticas, que geram um senso de coerência e auto-estima" (Manovich, 2017, p. 134, tradução nossa). O que muito nos diz, aliás, sobre a "sociedade do cansaço" (Byung-Chul Han, 2015) em que vivemos, onde reina absoluto o eu: por um lado, emoldurado pelos excessos de positividade e estímulos, pela linguagem publicitária e seus discursos motivacionais, de encorajamento e autoajuda; 11 por outro, preso a uma organização social coercitiva e perversa, em que nos tornamos carrascos de nós próprios, culminando em legiões de pessoas afetadas pela depressão, transtornos de personalidade e défices de atenção. Neste sentido, os trechos recortados da obra de Caio Fernando Abreu, marcada por aquela grande amplitude emocional que, no fundo, resulta nas muitas e muitas vezes reiterada "expressão de cansaço absoluto" (Abreu, 2002, p. 414), decerto funcionam como uma espécie de alento para uma dor crônica de jovens profundamente angustiados com as ultracompetitivas exigências da sociedade globalizante do "faça você mesmo".

Talvez esteja aí uma das possíveis explicações para o tipo de recorte massivamente propagado da obra de Caio Fernando Abreu no cosmos da web, no qual se prescinde inclusive daquela face do autor que nos "ajuda a compreender e atravessar melhor esses tempos brasileiros, os sonhos e as ansiedades de quem não abdicou de reivindicar urgência de felicidade no e para o país, enquanto estamos vivos e lúcidos" (Alabarse, 2002, p. 5). Como se pode ver pela ausência de memes de teor crítico-político, esses "tempos brasileiros" já não têm aqui qualquer interesse para compor o recorte que se inscreve na linguagem globalizada do Instagramism, com o seu exposto playtime da intimidade e uma coleção infindável de autorretratos continuamente editados em paisagens que podem ser identificadas em qualquer parte do mundo ou que, se não exóticas, já não interessam ser identificadas - é neste universo que Caio Fernando Abreu se torna atraente justamente "porque não sabia ser senão pessoal, impudico" (Alabarse, 2002, p. 7). Enfim, o que os recortes da obra difundidos na internet sugerem é que o interesse está tão somente nos "pequenos melodramas cotidianos" (Abreu, 2002, p. 121), para utilizarmos uma expressão do próprio escritor, cuja face exposta pode ser sintetizada na ideia de um eu que segue

\footnotetext{
${ }^{11}$ É interessante observar que muitos memes que circulam nos perfis intitulados Caio Fernando Abreu, com citações cuja referência não encontramos na obra, fazem uso recorrente da linguagem publicitária, empregando muitas vezes verbos no modo imperativo (seja, esteja, faça, ame, abrace são alguns dos verbos mais comuns). Além disso, Guilherme Viavaca, administrador do grupo fechado no Facebook que mencionamos há pouco, afirma que, ao longo dos últimos anos, "aumentou o número de posts que tenho que barrar: ou porque não são referentes à obra de Caio Fernando Abreu (vemos logo que não é o estilo textual dele), ou porque tem gente que entra para pedir curtidas em fotos do seu próprio perfil, ou mesmo insistem em postar citações de outros autores ou poemas próprios" (entrevista concedida para este trabalho, realizada a 26/03/2019, por $e$-mail; também entramos em contato com os administradores dos outros perfis aqui trabalhados, mas não obtivemos resposta).
} 
continuamente dizendo: "e enfrento, e reconstituo os pedaços, a gente enfeita o cotidiano tudo se ajeita" (Abreu, 2002, p. 123), como afirma ainda na mesma carta.

$8 \mathrm{~A}$

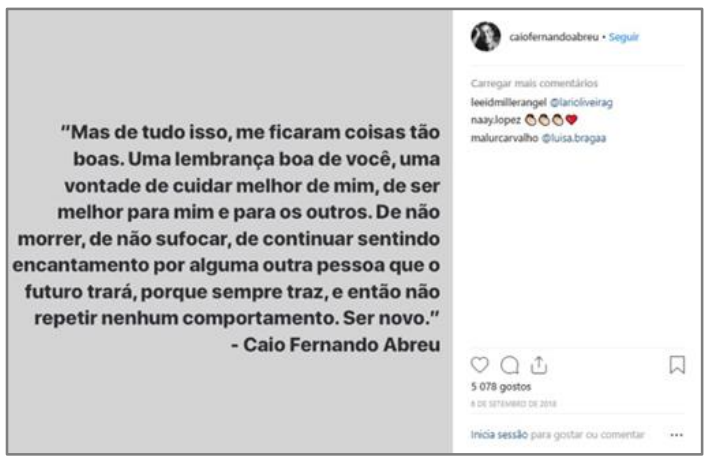

$8 \mathrm{~B}$

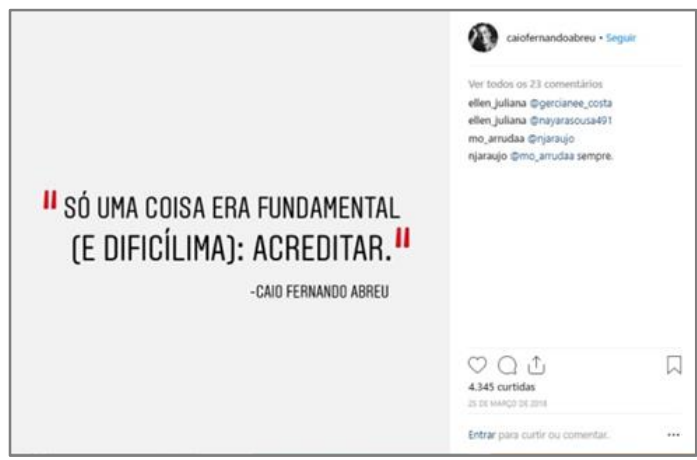

$8 \mathrm{C}$

"Meu Deus, não sou muito forte, não tenho muito além de uma certa fé. Preciso agora da tua mão sobre a minha cabeça. Que eu não perca a sobreach capacidade de amar, de ver, de sentir. Que eu continue alerta. Que, se necessario, eu possa ter novamente o impulso do vôo no momento exato. Que eu não me perca, que eu năo me fira, que não me firam, que eu não fira ninguém. Livra-me dos poços e dos becos de mim, Senhor. Que meus olhos saibam continuar se alargando sempre."

Caio Fernando Abreu

$8 \mathrm{D}$

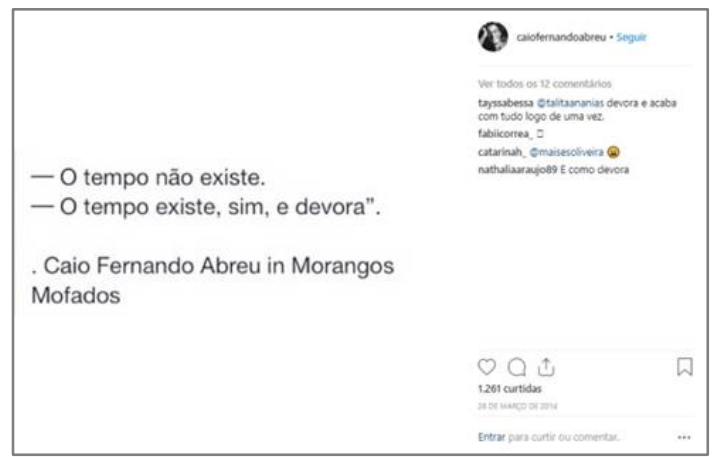

Figuras 8A, 8B, 8C e 8D - Memes publicados pelo perfil \#caiofernandoabreu, no Instagram. ${ }^{12}$

\footnotetext{
${ }^{12}$ Como se vê, o tipo de conteúdo recortado da obra de Caio Fernando Abreu converge quanto às temáticas realçadas, privilegiando os "pequenos melodramas cotidianos". A seguir, destacamos a origem das citações mencionadas nos memes acima: carta publicada na edição organizada por Italo Moriconi, de 2002 (8A); crônica "Uma história de fadas", publicada em Pequenas epifanias, de 1996 (8B); misto de diário e ficção intitulado "Lixo e purpurina", publicado no livro Ovelhas negras, de 1974 (8C); romance Morangos mofados, de 1982 (8D).
} 
Além disso, é importante observar que os personagens de Caio Fernando Abreu estão sempre em deslocamento, como de resto o próprio autor, que mesmo diante da doença, não deixou de fazer as suas grandes andanças pelo Brasil e pela Europa. "Inseguro, paranoico, só se sentia bem em trânsito, viajando com ou sem passaporte", diz Antonio Gonçalves Filho (2014, p. 8), na introdução de Pequenas epifanias. E ainda completa: "parecia caminhar com firmeza, mesmo sem saber que direção escolher. Simplesmente caminhava, à espera da graça, de uma epifania que o recompensasse pela longa caminhada" (Gonçalves Filho, 2014, p. 8). Se bem repararmos, reside nessa descrição um certo movimento que também nos é familiar neste mundo em rede, que implica precisamente percorrermos sem saber que direção escolher, sempre à espera de uma epifania, e talvez por isso essas novas gerações tanto se identifiquem com "o estilo de vida [lifestyle] de um errante pela estrada do século, derrotado pela fadiga e agonia, desesperado atrás de uma pequena epifania" (Gonçalves Filho, 2014, p. 8). Há qualquer coisa desse princípio de transformar as narrativas em breves experiências epifânicas que, entretanto, sobrevive na concepção das redes sociais, na maneira como transformam as narrativas do nosso cotidiano ao se expor os "Fragmentos disso que chamamos de "minha vida'", para utilizarmos uma das frases iniciais da crônica "Pequenas epifanias", que dá título ao livro. Se podemos pensar na obra deste autor como "o romance fragmentado de uma vida" (Moriconi, 2002, p. 10), talvez também possamos entender, afinal, que esse romance fragmentado de uma vida se tornou um dos princípios constitutivos dos perfis nas redes sociais.

\section{Clarice Lispector, musa das redes sociais}

No dia 2 de julho de 2011, o site humorístico Diário Pernambucano, que se descreve como "um site de notícias meio fake (falsas), meio reais", publicou a seguinte nota:

Usuários brasileiros das redes sociais Twitter e Facebook foram pegos de surpresa nesta última sexta-feira quando tentaram postar frases da escritora ucraniano-brasileira Clarice Lispector. Na tentativa de compartilhá-las, os usuários se depararam com a seguinte mensagem: "ERRO 409 - Minhas desequilibradas palavras são o luxo do meu silêncio". Paradoxalmente, trata-se de uma frase atribuída à própria Lispector. Segundo o especialista em segurança e bloqueios cibernéticos, Hélvio dos Anjos, a ativação do filtro "anti-lispector" é uma medida preventiva contra os últimos ataques feitos por hackers - em profunda crise existencial - aos sites do governo brasileiro. ${ }^{13}$

Como se vê, o efeito anedótico do breve relato "noticioso" só é possível por causa da tremenda popularidade de Clarice Lispector - seu nome, sua imagem, seu capital simbólico, tudo isso às vezes de maneira descolada de sua obra - nas redes sociais. No Instagram, o perfil Frases de Clarice (\#claricelispectorfrases) é publicado desde 2013 e conta, atualmente, com 60,6 mil seguidores (Figura 9). Já uma busca no Facebook nos leva a três páginas dedicadas ${ }^{14}$ à autora, totalizando, juntas, até agora, quase 1,3 milhão de seguidores (Figura 10). ${ }^{15}$

\footnotetext{
${ }^{13}$ Disponível em: http://www.diariopernambucano.com.br/noticias/frases-de-clarice-causam-caos-nas-redes-sociais/. Acesso em: 5 mar. 2019.

${ }^{14}$ Cabe uma observação relacionada ao que acima chamamos de "páginas dedicadas" a Clarice Lispector. Como veremos, nem todas as páginas que levam o nome da autora são verdadeiramente dedicadas à sua obra.

${ }^{15}$ Não levamos em consideração nem os perfis individuais, nem os grupos fechados que adotam o nome Clarice Lispector.
} 


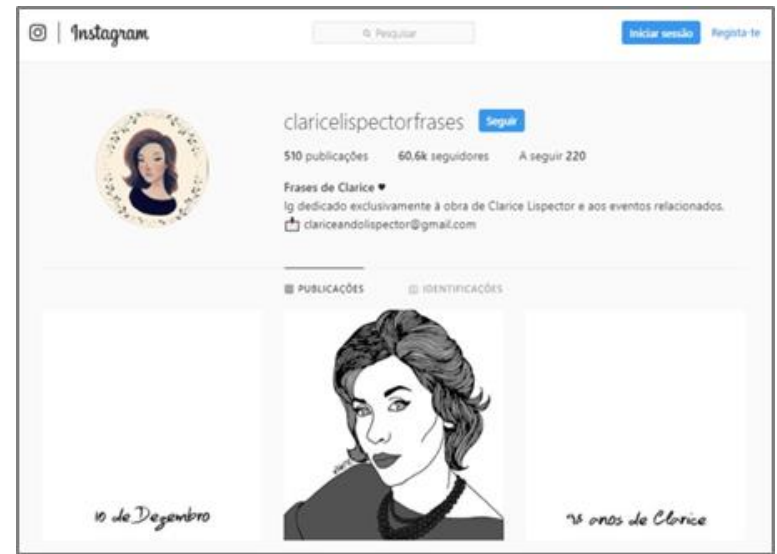

Figura 9 - Perfil Frases de Clarice (\#claricelispectorfrases), no Instagram. Prints realizados em 29 abr. 2019.

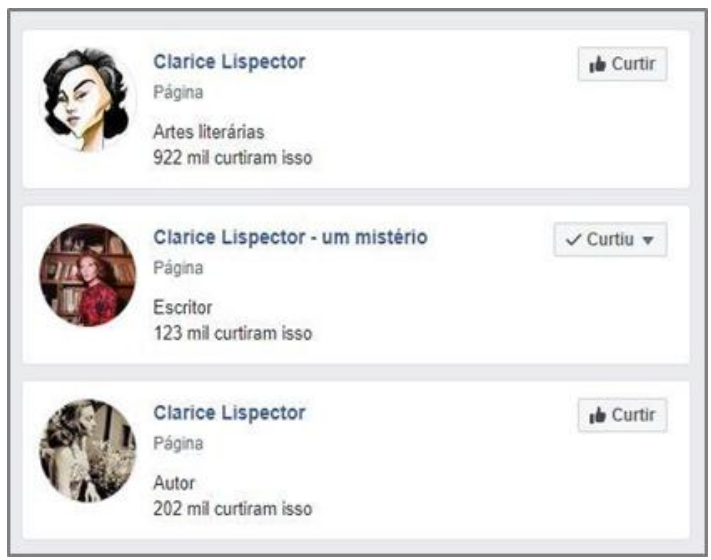

Figura 10 - Três páginas no Facebook que recebem o nome da autora: Clarice Lispector (@claricelispector15), Clarice Lispector - um mistério (@ClariceLispector.ummisterio) e Clarice Lispector (@AguaViva).

É pertinente retomar o post da jovem professora, leitora de Caio Fernando Abreu, para frisar que, inclusive nesse universo on-line, muitas vezes se tem ressaltado um espaço comum de criação que existe entre esses dois autores, denunciado enfaticamente em vários momentos pelo próprio autor de Pequenas epifanias, que inclusive começa o livro (cujo título é uma referência direta a Clarice) relatando um trecho que lhe é obsessivo de um conto da autora. Ao reiterar constantemente como os "textos lindíssimos e superinquietantes" (Abreu, 2002, p. 148) de Clarice lhe perturbam, Caio Fernando Abreu não hesitou em comentar várias vezes o quanto "Clarice, pra mim, é o que mais conheço de GRANDIOSO, literariamente falando" (Abreu, 2002, p. 460). Noutra desassombrada passagem, afirma ainda, em carta: "Clarice disse tudo? Certa vez um crítico do Le Magazine Litteraire disse que meu texto parecia 'o de uma Clarice Lispector que tivesse ouvido muito rock'n'roll e tomado algumas drogas'. Fiquei lisonjeadérrimo" (Abreu, 2002, p. 294). E esta atmosfera partilhada, como se vê, não poderia deixar de ser um fator de grande relevância a se considerar quando pensamos por que estes dois escritores ganharam notável projeção nas redes sociais.

Como se sabe, uma das características mais recorrentemente lembradas da prosa clariceana é a palavra epifânica: o valor do espanto envolto nos mistérios insondáveis do cotidiano, a presença do instante de iluminação, que se constrói a expensas da observação e do contato com o mundo prosaico. Trata-se do instante único que surge no ramerrão do dia a dia: durante a faxina no armário, no passeio pelo zoológico, no percurso de bonde na volta das compras, no voo desajeitado de uma galinha... O instante pinçado da massa cotidiana, na prosa clariceana, transcodifica-se nas redes sociais e os memes recortam, da massa textual dos densos romances, contos e crônicas de Clarice Lispector, as frases que 
melhor expressam a singularidade desses instantes. Mais uma vez, assim como vimos acontecer com Caio Fernando Abreu, a atmosfera do self se sobrepõe a qualquer outro tipo de conteúdo e reflexão que extrapole os limites da subjetividade. ${ }^{16} \mathrm{O}$ impacto no leitor é certeiro - quem não gostaria de ser atingido por uma abrupta epifania enquanto move-se pelo mar de informações, úteis e inúteis, da internet? - e se confirma nas milhares de curtidas nas postagens das páginas que mencionamos.

No entanto, notamos algumas especificidades no que diz respeito à construção dessa Clarice (dessas Clarices?) eminentemente autocentrada nas redes sociais. De maneira geral, nas três páginas do Facebook que investigamos, a Clarice Lispector que se constrói a partir dos textos (de sua autoria e/ou apócrifos), das imagens (fotografias da autora ou provenientes de bancos de imagens) e da própria interação que os seguidores mantém com essas páginas, a partir dos comentários às postagens, é uma Clarice Lispector que se equilibra entre a assertividade de uma posição feminina/feminista e a atitude altiva de quem pode aconselhar. No primeiro caso, a imagem construída poderia encontrar seu gérmen na obra da autora, não em termos de assertividade, mas quanto aos questionamentos feitos em torno do ser mulher-sujeito no mundo, tema frequente dos romances, contos e crônicas clariceanos. Aqui, há que se partilhar o incômodo que causa o adjetivo "feminista", que empregamos cientes da sua pouca pertinência nesse contexto, uma vez que o que poderia haver de "feminista" nos memes mais paradigmáticos das três páginas é totalmente destituído de qualquer teor político, de qualquer postura de contestação e problematização. O que resta de um "feminismo" destituído de postura política talvez não mereça ser chamado de feminismo: é assertividade em estilo coaching (Figuras 12A, 12B, 12C e 12D). No segundo caso, os conselhos construtivos a respeito dos mais variados temas existenciais não parecem encontrar eco nas obras da autora, cujos personagens estão sempre atormentados justamente com os nós da existência, com as questões irresolutas da vida.

\section{$12 \mathrm{~A}$}

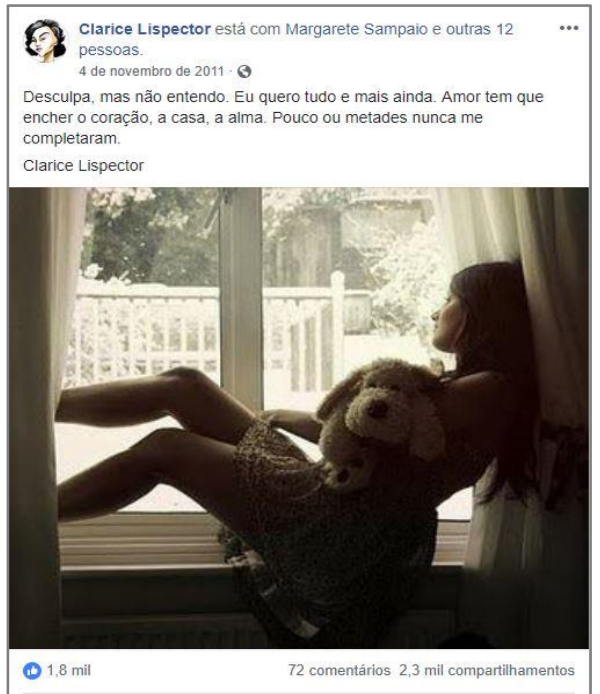

$12 \mathrm{~B}$

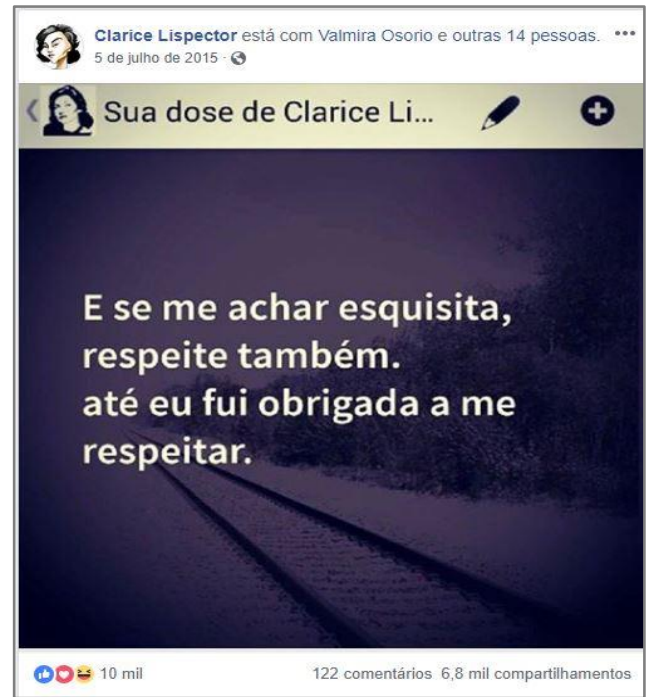

\footnotetext{
${ }^{16}$ Natália Correira, responsável pela conta Frases de Clarice (@claricelispectorfrases), no Instagram, nota que os memes que alcançam maior popularidade são aqueles que reproduzem frases que "falam do $e u$ na primeira pessoa" (entrevista concedida para este trabalho, realizada em 11 de março de 2019, por e-mail; também entramos em contato com os administradores dos outros perfis aqui trabalhados, mas não obtivemos resposta).
} 
$12 \mathrm{C}$

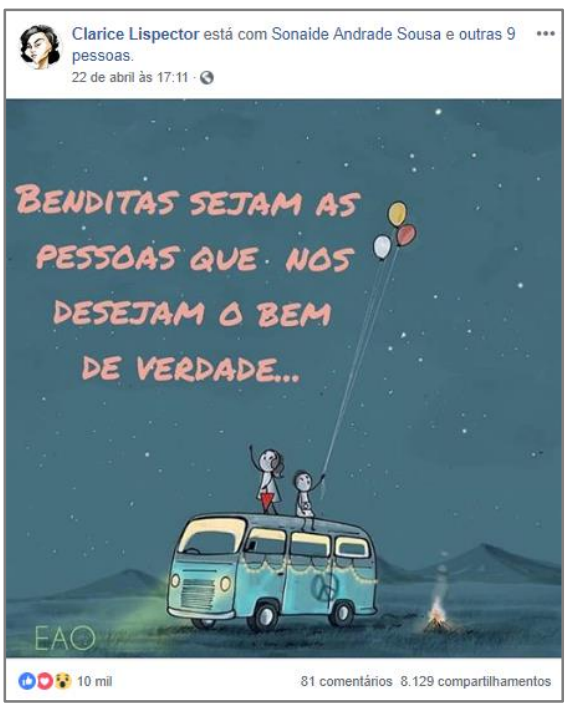

$12 \mathrm{D}$

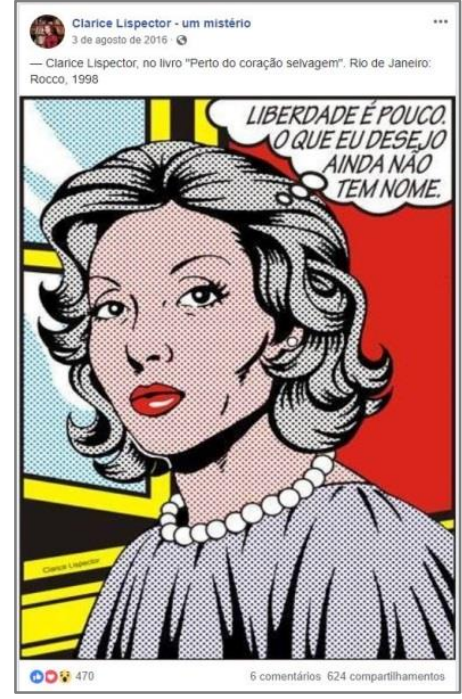

Figuras 12A, 12B, 12C e 12D - Prints retirados das páginas Clarice Lispector (@claricelispector15) e Clarice Lispector - um mistério (@ClariceLispector.ummisterio). ${ }^{17}$

Ao contrário do caso de Caio Fernando Abreu, em que fotografias nas fanpages são raras, a imagem de Clarice Lispector, documentada em vasta iconografia, é fartamente utilizada. Pode estar aí uma das explicações plausíveis para a sua imagem simbólica que circula nas redes sociais (Figuras 13 e 14): a performance de Clarice nas fotografias favorece a imagem de uma mulher elegante e segura de si, que certamente influencia na seleção das citações que circulam sob a marca Clarice Lispector.

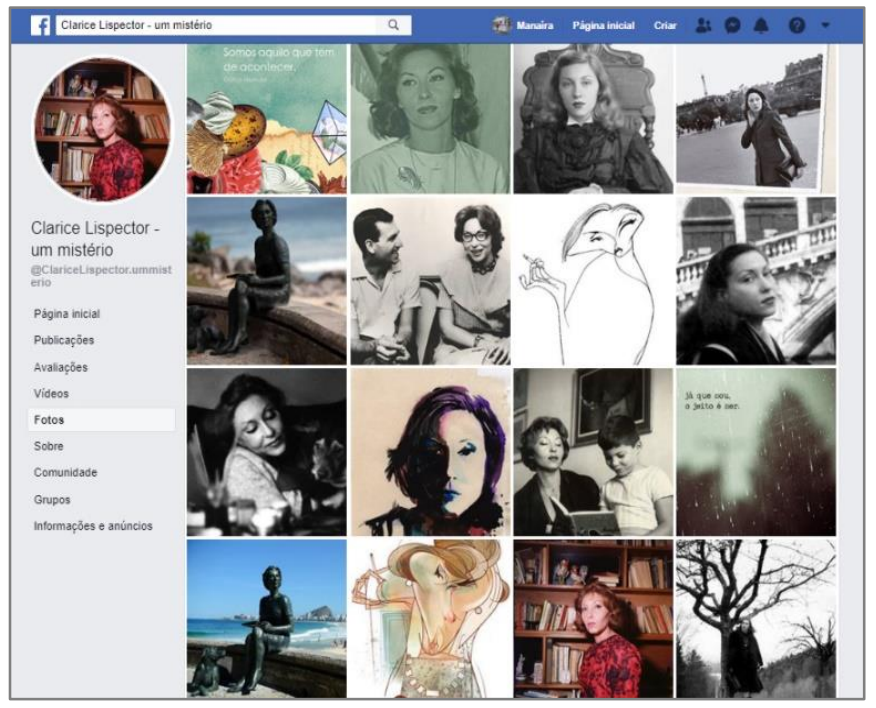

Figura 13 - Imagens publicadas pela página Clarice Lispector um mistério (@ClariceLispector.ummisterio).18

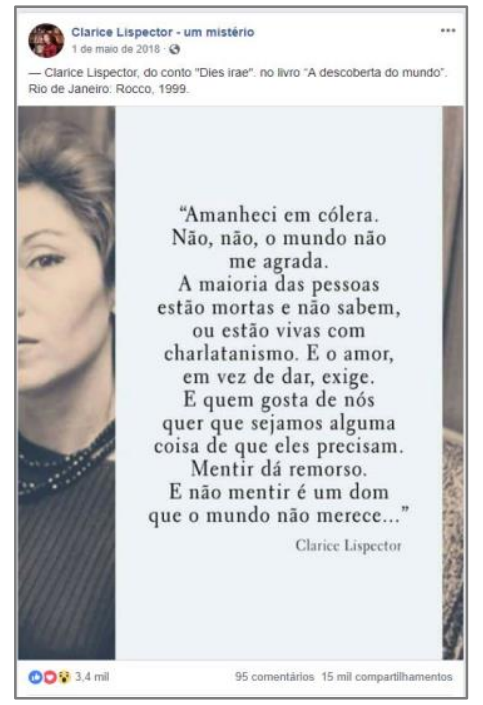

Figura 14 - Meme divulgado na mesma fanpage, construído a partir do close up no semblante da escritora.

\footnotetext{
${ }^{17}$ Esses prints evidenciam o tipo de citações que prevalecem nos memes: predomínio da primeira pessoa e assertividade em estilo coaching.

${ }^{18}$ As imagens revelam a importância da edição e difusão de fotografias da autora para a construção da sua(s) imagem(ns) no mundo on-line
} 
As fotografias de Clarice, tal como as citações, são selecionadas, recortadas, manipuladas: na maioria dos casos, deparamo-nos com imagens em preto e branco, que enquadram o rosto sério da autora, no máximo o seu torso, deixando para trás o "resto" da fotografia original, com o seu ambiente e uma possível indicação de ação que a foto poderia sugerir, para se ater apenas ao enquadramento da face (facilitada pela própria disposição quadrada que orienta o design daquelas redes sociais). Esse recorrente recurso de close up no rosto da escritora indicia aquela procura pela expressividade emocional, pelos gestos que desencadeiam sensações, pela criação de uma nova atmosfera alcançada com a edição. É difícil afirmar, nesse sentido, se as fotografias de Clarice ilustram uma imagem que se constrói pelos fragmentos textuais de sua obra que circulam pelas redes, ou se, em vez disso, as imagens motivam uma leitura, seleção e recorte específicos de sua obra. O mais provável é que as duas coisas funcionem conjuntamente.

A tonalidade que chamaríamos de "construtiva" das versões da obra clariceana que circulam pelas redes parece ter alvo certo. É o que se pode apreender pela análise das imagens que acompanham os fragmentos e frases da autora, seja no Facebook, seja no Instagram: o público feminino. Embora, à primeira vista, possa parecer que há variedade nas imagens que constituem os memes nas páginas analisadas, um olhar um pouco mais atento evidencia que, entre as imagens que retratam figuras humanas (há muitas paisagens e imagens não figurativas, provenientes de bancos de imagens, na maioria dos casos) e que não são fotografias de casais, $100 \%$ delas são fotografias de mulheres. O que aponta para um estreitamento radical da recepção da obra clariceana no universo digital: considerando a grande probabilidade de os memes dessas páginas serem direcionados sobretudo às mulheres, o $e u$ que se expressa na maioria das frases e fragmentos dos memes é, forçosamente, feminino, por expressar sentimentos de personagens femininas daquela obra ou porque se compreende que expressaria os sentimentos da própria Clarice Lispector?

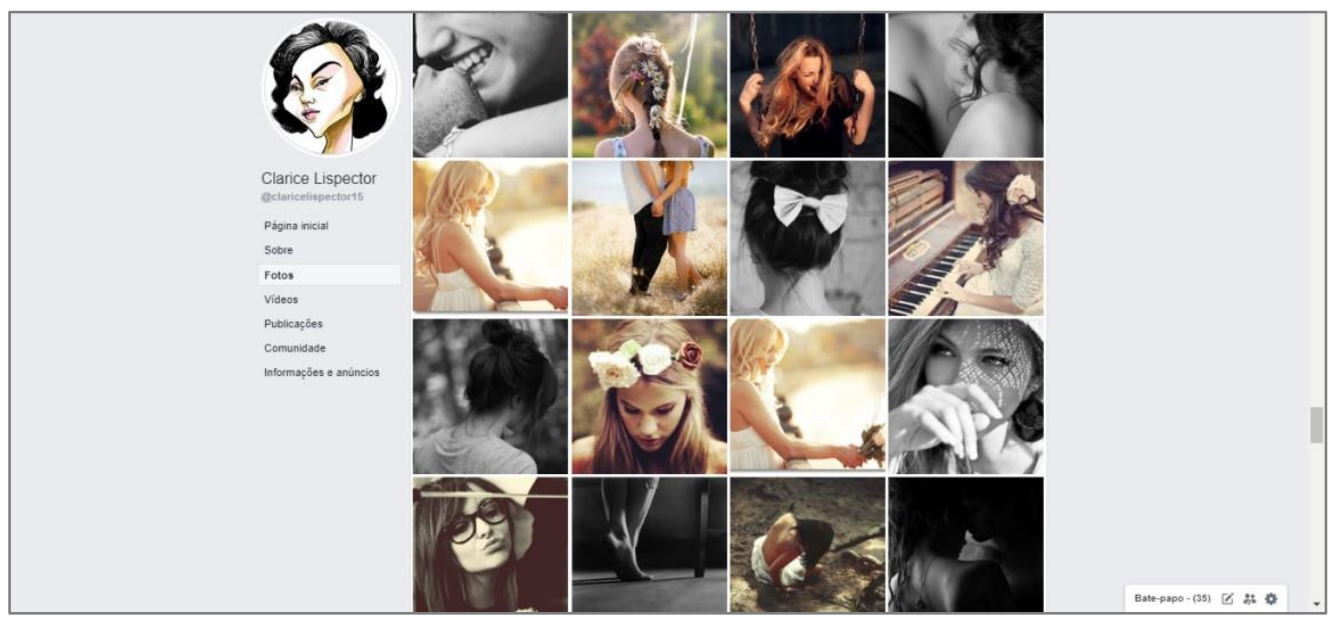

Figura 15 - Print com imagens da primeira fase da página Clarice Lispector (@claricelispector15), no Facebook.19

Quer nos parecer que essa confusão entre obra e autor existe, o que reitera uma busca pela segmentação do público-alvo bem maior do que aquela com que nos deparamos no caso de Caio Fernando Abreu. Basta ver, por exemplo, uma ação de divulgação realizada no Frases de Clarice (\#claricelispectorfrases), no Instagram, quando, entre agosto e outubro de 2014, num tom de campanha publicitária, os memes da página foram criados com a "frase preferida" de cada um dos seguidores selecionados, justapostas às suas fotografias pessoais modificadas com aqueles filtros que dão aparência desbotada às imagens, lembrando o padrão do tipo de meme que descrevemos anteriormente. Entre esses memes, apenas um traz a fotografia de um rapaz, o que o destaca, por isso, entre os(as) seguidores(as) da página.

\footnotetext{
${ }^{19}$ Observa-se aqui o mesmo tipo de meme que encontramos em fases iniciais das páginas @ caiofernandoabreu e \#escritorcfabreu.
} 


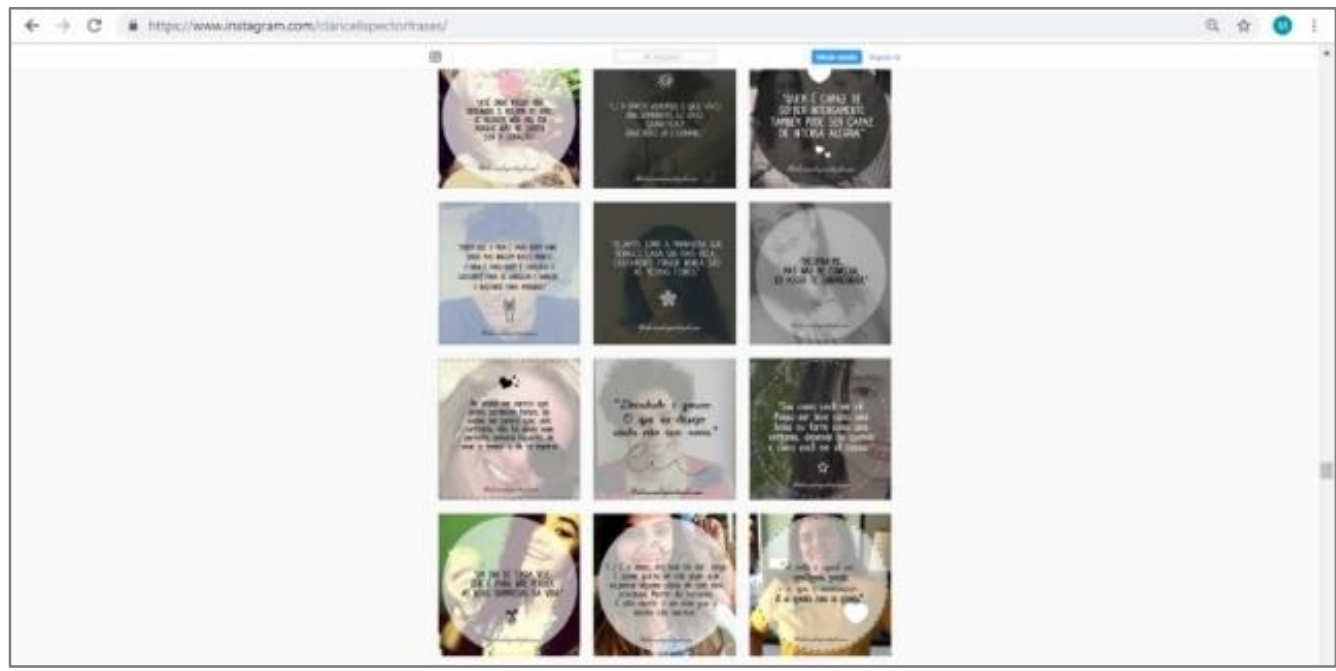

Figura 16 - Print da ação de divulgação promovida pelo Frases de Clarice (\#claricelispectorfrases), em que fotos de seguidores serviram como base para a construção de memes.

Dessa forma, a circulação e fixação dessas imagens da Clarice Lispector das redes sociais vão consolidando-a como uma marca que, muitas vezes, viabiliza que o nome da escritora, no Facebook e no Instagram, seja associado a lugares, pessoas e atividades que mantêm uma relação muito distante ou que nem sequer mantêm relação alguma com a literatura. No caso de duas das páginas que estamos estudando, tal fenômeno é claramente verificável pelo fato de que, em determinada altura, ambas deixaram de ser "dedicadas" à autora e, embora mantendo o seu nome no título, passaram a tratar de assuntos os mais diversos, repostando conteúdo produzido por outras páginas ou por outros veículos de comunicação. ${ }^{20}$ É o caso da página mais seguida e curtida, Clarice Lispector (@claricelispector15), com os seus atuais 943 mil seguidores. O perfil surgiu, no Facebook, em 23 de maio de 2011, com aquele tipo de meme que também prevaleceu durante muito tempo nos assinalados perfis com o nome de Caio Fernando Abreu, trazendo uma fotografia, provavelmente proveniente de bancos de imagens, encabeçada no post por uma citação atribuída ao autor. Já no primeiro ano, alguns dos memes assim padronizados ultrapassaram as mil curtidas e os mil compartilhamentos. Um ano depois, postagens com o mesmo perfil estrutural - e, há que se sublinhar, com aqueles perfis temáticos que já mencionamos anteriormente - alcançaram mais de 5 mil compartilhamentos.

Entre 2012 e 2015, período de pouca atividade na página, um meme - com a frase “Não me deixe ir, posso nunca mais voltar" - se destaca por seu alcance: publicado em 8 de maio de 2013, atinge mais de 7 mil curtidas e é compartilhado 12 mil vezes. O curioso é que esse mesmo meme já havia sido compartilhado pela página duas vezes, atingindo números expressivos de forma progressiva, $\mathrm{o}$ que mostra a curva ascendente do perfil: no post de 7 de março de 2012, o meme recebe 207 likes e 687 compartilhamentos e, depois, em 30 de maio de 2012, já conta com 2 mil likes e 7.559 compartilhamentos. A sua estrutura é diferente da descrita anteriormente, uma vez que, nela, texto e imagem se justapõem, e apesar de haver a inscrição do nome da autora no espaço gráfico do meme, não é feita a indicação da fonte. É aquela terceira postagem do meme, portanto, que atua como um divisor de águas, pois a partir dela, no Clarice Lispector (@claricelispector15), aqueles memes padronizados com imagens sugestivas acompanhadas da citação em post (que geralmente vinham com o nome da autora, mas não com a referência da fonte), que dominaram toda a página até a altura (Figuras 17A, 17B e 17C), deixam de ser utilizados. Em seguida, começam a surgir memes

\footnotetext{
${ }^{20} \mathrm{O}$ mesmo acontece com a segunda página no Facebook que recebe o nome de Caio Fernando Abreu (@SoUmSentimento) e mais adeptos têm, com atuais 613 mil seguidores, tendo sido criada em 14 de maio de 2012. O caráter publicitário fica logo evidente na apresentação da página, em que a única informação que existe é o "contato para publicidade", informando um endereço de $e$-mail. Outra página no Facebook que também publica conteúdos diversos, inclusive repostando notícias de vários sites, é a Caio Fernando Abreu (@caiofernandoabreu15), criada em 29 de abril de 2011 e atualmente com 368 mil seguidores.
} 
com design irregular - e, no entanto, mais preocupados em inscrever o nome da autora no espaço gráfico e também a indicação do livro de onde a citação foi retirada. Dessa nova fase do perfil, $40 \%$ dos memes trazem a indicação da fonte, o que é substancial quando comparamos com o padrão antes estabelecido. Assim como no caso de Caio Fernando Abreu, é oportuno observar que, de 2016 para cá, passou a ser mais comum a preocupação em mencionar o livro do qual o trecho foi retirado - e, voltamos a dizer, parece interessante que esse comportamento tenha surgido numa altura em que começaram a acontecer debates mais intensos sobre a difusão em massa de fake news, com constantes alertas para que o público cheque as fontes e coloque em causa muito do conteúdo que circula em rede. É nessa mesma altura que, no Frases de Clarice, no Instagram, os conteúdos também começam a receber mais frequentemente a indicação da sua origem no cabeçalho do post.

\section{$17 \mathrm{~A}$}

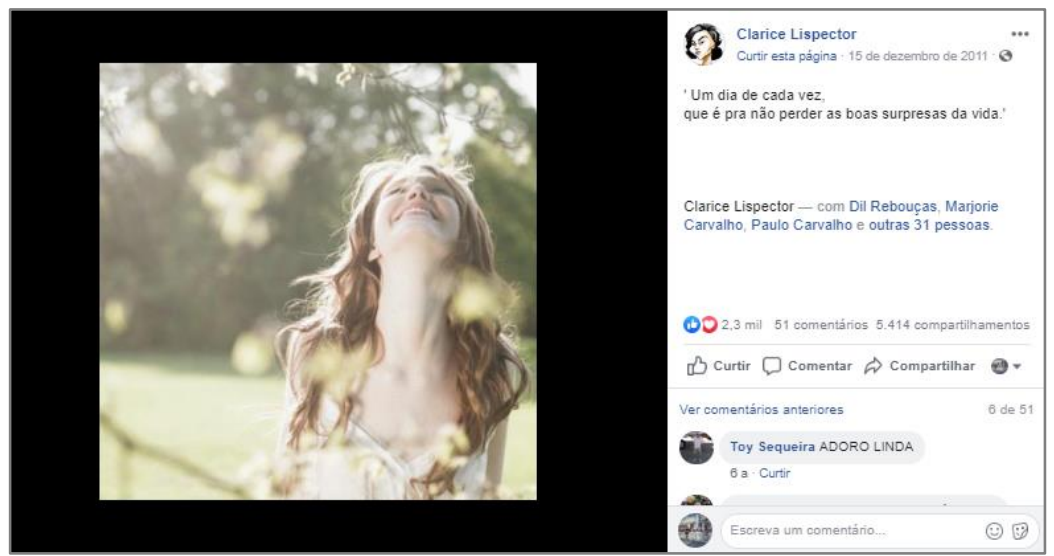

$17 \mathrm{~B}$

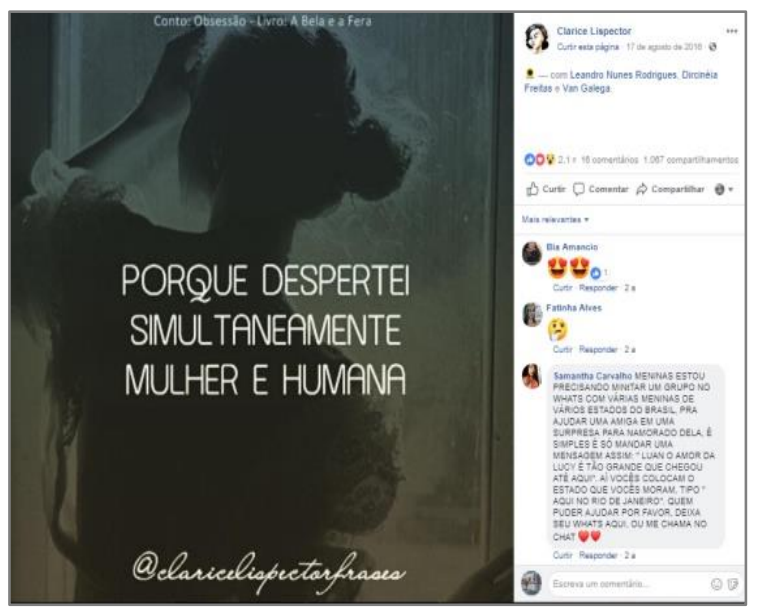

$17 \mathrm{C}$

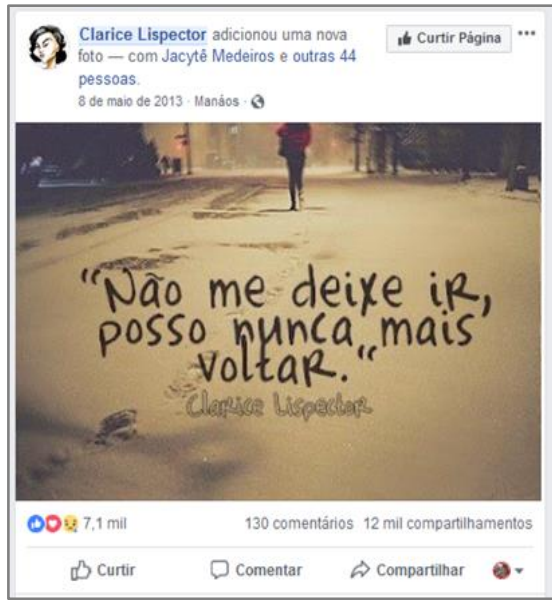

Figuras 17A, 17B e 17C - Memes que representam diferentes fases da página Clarice Lispector (@claricelispector15).

Outro caso relevante para a nossa investigação é o da página Clarice Lispector - um mistério (@ClariceLispector.ummisterio), iniciada em 14 de novembro de 2015, contando atualmente com 125 mil seguidores. Até maio de 2016, publicava predominantemente frases de Clarice Lispector, geralmente referenciadas e sem praticamente nenhuma imagem; raramente as postagens alcançavam mais de 50 curtidas e poucas eram compartilhadas. O ponto de viragem na popularidade da página se deu no dia 21 de maio de 2016, com a postagem da crônica "Das vantagens de ser bobo", com voz em off de Aracy Balabanian e foto de Clarice Lispector, que atingiu 
a marca das 647 mil visualizações, 2 mil likes e 18 mil compartilhamentos. Tal vídeo acabou por inaugurar uma nova fase da fanpage, que começou a trazer memes com imagens e textos justapostos, alcançando milhares de compartilhamentos, embora nem sempre o número de curtidas seja alto (Figuras 18A, 18B, 18C e 18D). O que chama a atenção nesta página, no entanto, é que, independente da sua fase, desde o início houve uma notável preocupação em publicar os memes indicando não apenas o livro do qual a citação foi retirada, mas inscrevendo no post a referência completa (cidade, editora e ano), acabando por promover as edições da Editora Rocco, que aparecem massivamente nas referências. Além disso, também notamos a preocupação em indicar o autor da ilustração que acompanha a citação ou o acervo ao qual pertence a fotografia utilizada. A partir de outubro de 2018, tornaram-se predominantes os memes compostos por imagens dos livros com a citação destacada num fundo embaçado e a indicação da referência ao lado do post. Por sua vez, desde abril de 2019, começaram a investir num novo tipo de meme, que traz a referência do nome do livro, cidade, editora e ano na própria composição visual do meme e, ainda, uma espécie de logotipo das instituições responsáveis pela página.

$18 \mathrm{~A}$

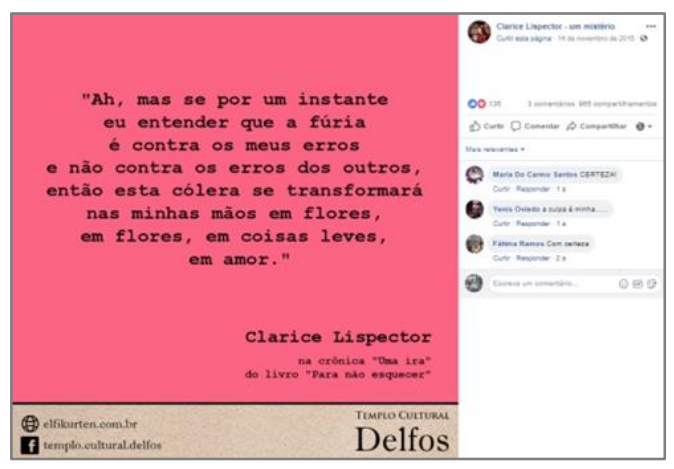

$18 \mathrm{C}$

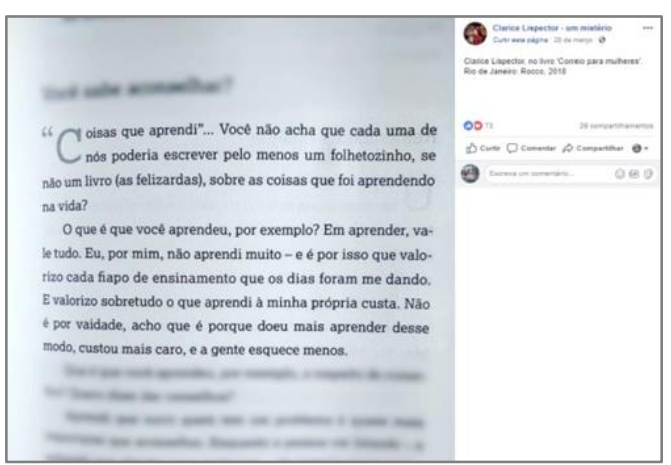

$18 \mathrm{~B}$

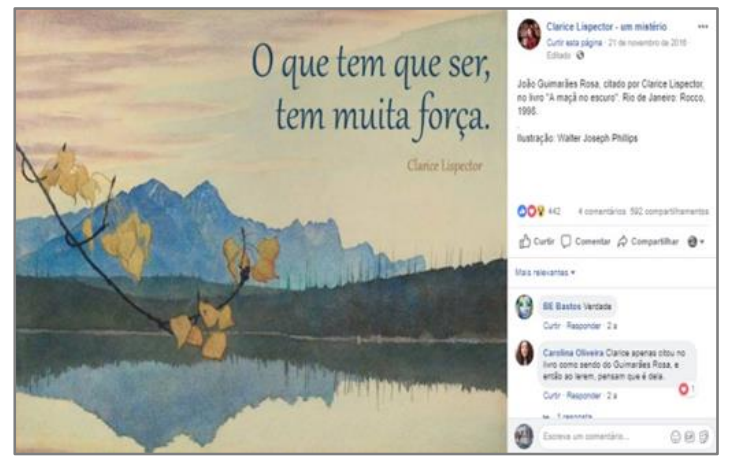

$18 \mathrm{D}$

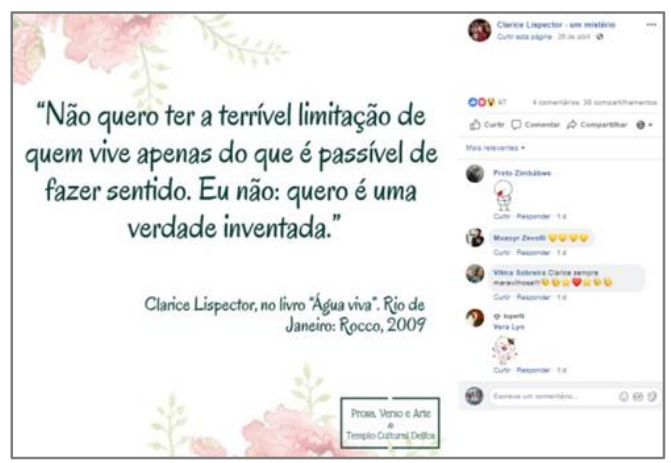

Figuras 18A, 18B, 18C e 18D - As diferentes fases da página Clarice Lispector - um mistério (@ClariceLispector.ummisterio) representadas pela alteração no modelo de memes.

Diante dessas descrições, como se pode notar, o percurso das duas páginas é parecido, a despeito de terem sido iniciadas com cinco anos de diferença: começam com postagens que trazem exclusivamente citações ou citações e imagens não justapostas, alcançam um ponto de viragem que está relacionado, em ambos os casos, com uma modificação da estrutura dos memes e, por fim, ambas passam a publicar conteúdos produzidos por outras mídias, nos dois casos, revistas eletrônicas. A página Clarice Lispector (@claricelispector15), em junho de 2018, começa a veicular conteúdo produzido pela Revista Pazes e a página Clarice Lispector - um mistério (@ClariceLispector.ummisterio) passa a remeter suas postagens à Revista Prosa, Verso e Arte, desde junho de 2016. Este, aliás, é o caso mais curioso, porque desde o início os seus primeiros memes revelam a vinculação da sua gestão ao Templo Cultural Delfos, um repositório digital de conteúdos 
culturais, educacionais, artísticos e científicos, criado, no início de 2011, com o intuito de reunir referências biobibliográficas de autores de língua portuguesa. Depois, esse mesmo repositório fundou a revista que cooptou o público da página, o que revela como as teias da convergência midiática estão presentes desde o início, daí inclusive o perfil mais institucional daquela fanpage, com as perceptíveis preocupações em fazer referências bibliográficas completas, diferenciando-se de outros perfis e publicitando organizações editoriais.

O caso da página Clarice Lispector (@AguaViva), criada em junho de 2012, é um pouco diferente dos dois anteriores: a maior parte de suas postagens são feitas em espanhol, embora também haja publicações em inglês, e quase todos os memes têm origem na repostagem de outras páginas. O que predomina são trechos curtos de obras de Clarice Lispector, traduzidos para aquela língua, notícias a respeito de suas obras, publicadas por veículos de comunicação diversos, mas nunca brasileiros, e a divulgação de eventos (espetáculos, lançamentos de livro, exposições) relacionados à escritora. $\mathrm{O}$ número de postagens é bastante baixo e frequentemente se passam meses sem que haja uma única publicação. Apesar de tudo isso, a fanpage é seguida por cerca de 202 mil pessoas, o que volta a levantar a questão da marca Clarice Lispector, cuja dimensão que vai tomando chega a eximir os administradores, nas redes sociais, da necessidade de publicar conteúdos regularmente. O nome Clarice Lispector é, em si, uma marca que, ainda que associada a conteúdos diversos, muitas vezes dissociados da obra literária, continua exponencialmente arregimentando seguidores. ${ }^{21}$

\section{Outros circuitos do literário: alguns pontos possíveis de chegada}

Quando observamos o panorama apresentado, não nos parece nada contingente que sejam duas obras que se encontram sincronicamente vinculadas (mais não fosse Caio, em certa medida, um "herdeiro" de Clarice) que despontem com tanta projeção no mundo digital. Se Caio Fernando Abreu é o "fotógrafo da fragmentação contemporânea", então Clarice Lispector é a própria fotografia desfragmentada nesse mundo on-line de narrativas dispersas: as imagens que circulam desses escritores apontam para a avalanche das questões de identidade que conquistam espaço com a multiplicidade de vozes que surgem - e só podem surgir - porque certas características do suporte midiático digital o permitem. Pela primeira vez na nossa história, as gerações mais jovens não necessitam do aprendizado das mais velhas para dominar as ferramentas de trabalho, que pela primeira vez na história também são, ao mesmo tempo, ferramentas de entretenimento. Neste contexto, diríamos que as idealizações proporcionadas pelo universo virtual (com o seu "vir a ser") a partir da nossa autoedição constante favorecem a dissolução entre o literário e o não literário, a exposição da intimidade ficcionalizada e a dispersão da referencialidade, a busca por um estilo transgressivo coadunado com o discurso de afeto, o estado de urgência de um mundo assolado pelo desamparo trágico contrastado pelo ideal do estilo de vida perfeito.

Nesta época em que as encenações da subjetividade ganham espaço com o estímulo ao constante falar de si, é significativo que tenham tido projeção entre as gerações mais jovens que dominam as redes sociais dois autores que reconfiguraram produções literárias em primeira pessoa e narrativas de cunho autobiográfico, levando-nos a repensar as noções de autor e narrador, além de terem investido na dissolução de fronteiras entre gêneros literários ("gêneros não me interessam mais", já dizia Clarice) e dado importância a gêneros que eram convencionalmente considerados menores, como cartas, crônicas, diários. Se pensarmos de que maneira a estrutura e a forma das novas mídias vetorizam a compreensão desses autores, localizando-os em um determinado espaço social constituído pela recepção de suas obras e pelo agenciamento de leitores, diríamos mesmo que essas obras conseguiram se conectar à "geração que enaltece a qualidade bluetooth" (Bicecci e Cobos, 2012, p. 52). Essa geração está sempre aberta para receber e repassar informações, num processo constante de intercâmbio, em que interessa a comunicação que se expande numa estrutura horizontal e

\footnotetext{
${ }^{21}$ A título de curiosidade, se procurarmos por "Clarice Lispector" tanto no Facebook quanto no Instagram, encontraremos grupos, páginas e contas com o seu nome dedicados às mais variadas atividades e produtos, dentre os quais escolas, grêmios estudantis, bibliotecas e páginas pessoais que oferecem serviços variados.
} 
superficial movida por hiperligações. Os ininterruptos receber e repassar informações desdobramse, em termos estéticos, em um contexto cultural descrito como o da reciclagem (Klucinskas e Moser, 2007), quando a tríade cópia, reciclagem e seriação vai assumindo novos valores graças, entre outras coisas, à facilidade com que se pode, no contexto das mídias digitais, fazer convergir imagem, som e texto selecionados nos inúmeros bancos de dados disponíveis na web, possibilitando a criação de produtos culturais diversos.

É diante do "verdadeiro épico do cotidiano, [...] com o sublime histérico que nosso tempo hedonista-consumista oferece em migalhas" (Moriconi, 2002, p. 11), que assistimos nas páginas analisadas a ausência de conteúdos (sejam eles textuais, sejam eles imagéticos) perturbadores, politicamente engajados, desconfortáveis ou problematizadores, o que é notoriamente tangencial em se tratando de Clarice Lispector e de Caio Fernando Abreu. Nas redes sociais, muitas vezes vai se dando origem à imagem de um autor que se descola de suas obras, o que parece acontecer mais radicalmente quando tratamos da conjuntura de Clarice Lispector no mundo on-line - e, aqui, a força de sua "marca", maior que a de Caio Fernando Abreu (talvez porque mais canônica, encontrando notável espaço não só no universo acadêmico, como sendo bastante difundida no ambiente escolar), provavelmente facilita o apagamento intermitente de sua obra em detrimento de citações apócrifas. É interessante observar que, nesse processo, uma obra tão densa, problematizadora e, mesmo incômoda, ao ser transposta para as redes sociais a partir de recortes deste tipo, vai dando origem a uma Clarice que é já outra coisa. O resultado é que se Clarice Lispector parece ter um efeito, enquanto marca, maior do que o de Caio Fernando Abreu, a verdade é que a obra dele tem perdurado mais espontaneamente nas redes, sem a cooptação institucional de editoras, por exemplo, e é mantida por públicos que produzem, ao mesmo tempo que consomem, um mesmo produto midiático.

Se no caso de Caio Fernando Abreu a convergência está no próprio conteúdo de design padronizado que passa a ser reproduzido pelos vários perfis no Facebook e no Instagram, no caso de Clarice Lispector tal modelo convergente, noutra face já, é levado ao extremo. As dimensões institucionalizadas de seu nome, provavelmente reforçadas por sua posição canônica, como dissemos, arregimentam fluxos de conteúdos através de vários suportes midiáticos e promovem o entrelaçamento de múltiplos mercados, "onde as velhas e as novas mídias colidem, onde mídia corporativa e mídia alternativa se cruzam, onde o poder do produtor de mídia e o poder do consumidor interagem de maneiras imprevisíveis" (Jenkins, 2008, p. 7). Este nosso estudo de caso mostra, com efeito, como a cultura do consumo gera diferentes narrativas a partir dos mesmos bancos de dados - o que justifica inclusive a convergência no tipo de meme adotado em perfis associados aos dois autores, em tempos em que, a contrapelo, "minimizamos a narrativa (o eixo sintagmático) em favor de banco de dados (o eixo paradigmático)" (Manovich, 2002, p. 168). Estamos diante da capitalização dos nomes dos autores como recursos de investimento: continuam a surgir mais e mais páginas e perfis e grupos, e inclusive alguns deles apresentam um só título: "Clarice Lispector e Caio Fernando Abreu". ${ }^{22}$ Afinal, é bom lembrarmos que, como diria um leitor daquela notícia com a qual começamos este artigo: "Agora até os poemas têm vírus" (Queirós, 2019).

\section{Referências}

ABREU, Caio Fernando (2002). Cartas. Organização de Italo Moriconi. Rio de Janeiro: Aeroplano.

ABREU, Caio Fernando (2014). Pequenas epifanias. 4. ed. Rio de Janeiro: Nova Fronteira.

ALABARSE, Luciano (2002). Prefácio. In: ABREU, Caio Fernando (2002). Cartas. Organização de Italo Moriconi. Rio de Janeiro: Aeroplano.

AVENDAÑO, Tom C. (2018). Caio Fernando Abreu é jovem como sempre, relevante como nunca. El Pais, 12 set. Disponível em: https:/ / bit.ly/2QqklQq. Acesso em: 20 abr. 2019.

\footnotetext{
${ }^{22}$ É interessante observar a descrição do grupo fechado Clarice Lispector e Caio Fernando Abreu, no Facebook, criado em 18 de agosto de 2013 e com, atualmente, quase 10 mil membros: "O grupo foi criado para homenagear Clarice e Caio. Nosso objetivo é compartilhar frases e obras de grandes e pequenos escritores", o que pressupõe que as obras dos homenageados servem de subterfúgio para a criação de um universo que inclui uma série de outros autores à partida.
} 
BICECCI, Verónica Gerber; COBOS, Carla Pinochet (2012). La era de la colaboración. mapa abreviado de nuevas estrategias artísticas. In: CANCLINI, Néstor García et al. (Org.). Jóvenes, culturas urbanas y redes digitales. Madrid: Fundación Telefónica; Barcelona: Editorial Ariel.

CASTRO, Juliana (2011). Morto há 15 anos, Caio Fernando Abreu está vivo nas redes sociais, é cultuado por jovens e ganha livros, documentário e peça. O Globo, Cultura, 15 mar. Disponível em: https://glo.bo/2tDxKeX. Acesso em: 20 abr. 2019.

DAWKINS, Richard (1976). The selfish gene. Oxford: Oxford University Press.

GONÇALVES FILHO, Antonio (2014). As últimas palavras de Laika. In: ABREU, Caio Fernando. Pequenas epifanias. 4. ed. Rio de Janeiro: Nova Fronteira.

HAN, Byung-Chul (2015). Sociedade do cansaço. Tradução de Enio Paulo Giachini. Petrópolis: Vozes.

JENKINS, Henry (2008). Cultura da convergência. Tradução de Susana Alexandria. 2. ed. São Paulo: Aleph.

KLUCINSKAS, Jean; MOSER, Walter (2007). A estética à prova da reciclagem cultural. Scripta, Belo Horizonte, v. 11, n. 20, p. 17-42, jan./jun. Disponível em: https://bit.ly/35s9ABp. Acesso em: 20 abr. 2019.

MALINI, Fábio (2014). Literatura, Twitter e Facebook: a economia dos likes e do RTS dos usuários fãs de literatura brasileira nas redes sociais. Observatório Itaú Cultural, São Paulo, n. 17, p. 204-232, ago./dez. Disponível em: https:/ / bit.ly/2SYzI4g. Acesso em: 21 abr. 2019.

MANOVICH, Lev (2002). Banco de dados como gênero das novas mídias - as formulações de Lev Manovich. Galáxia, São Paulo, n. 3, p. 167-177. Disponível em: https://bit.ly/302fKr2. Acesso em: 4 abr. 2019.

MANOVICH, Lev (2005). El lenguaje de los nuevos medios de comunicación. Tradução de Oscar Fontrodona. Barcelona: Paidós.

MANOVICH, Lev (2011). Cultural software. Disponível em: https:/ / bit.ly/36ue8IW. Acesso em: 5 mar. 2019.

MANOVICH, Lev (2017). Instagram and contemporary image. E-book. Disponível em: https://bit.ly/2ZVxbcx. Acesso em: 5 mar. 2019.

MORICONI, Italo (2002). Introdução. In: ABREU, Caio Fernando. Cartas. Organização de Italo Moriconi. Rio de Janeiro: Aeroplano.

PORTELA, Manuel (2012). Introdução: literatura no século XXI. Revista de Estudos Literários, Coimbra, v. 2, p. 5-22. Disponível em: https:// bit.ly/2QtCflo. Acesso em: 10 mar. 2019.

QUEIRÓS, Luis Miguel (2019). Um falso poema de Sophia que se tornou viral. Ípsilon. 4 fev. Disponível em: https:// bit.ly/2SVowp1. Acesso em: 10 mar. 2019.

THOMPSON, John B (2012). Mídia e modernidade. 13. ed. Tradução de Wagner Oliveira Brandão. Rio de Janeiro: Petrópolis.

VENTICINQUE, Danilo; AYUB, Isabella (2002). Autor que renasceu na internet: Caio Fernando Abreu vira ídolo teen 16 anos depois de sua morte. Época, São Paulo, 30 mar.

VIEIRA, Ana Gabriela Lima (2011). Clarice Lispector por Caio Fernando Abreu. Anagabigabriela - Eu e meus pitacos sobre a vida. Blog pessoal. Disponível em: https:// bit.ly/2QrpvMc. Acesso em: 10 mar. 2019. 